\title{
Microstructure and Mechanical Properties of Rapidly Solidified $\beta$-Type Ti-Fe-Sn-Mo Alloys with High Specific Strength and Low Elastic Modulus
}

\author{
Peiyou Li ${ }^{1} * \mathbb{C}$, Xindi Ma ${ }^{2}$, Yuefei Jia ${ }^{2}$, Fanying Meng ${ }^{1}$, Ling Tang ${ }^{1}$ and Zhirong He ${ }^{1}$ \\ 1 School of Materials Science and Engineering, Shanxi University of Technology, Hanzhong 723001, China; \\ aboying@yahoo.com (F.M.); snuttang@163.com (L.T.); hezhirong01@163.com (Z.H.) \\ 2 School of Materials Science and Engineering, Shanghai University, Shanghai 200444, China; \\ Melodyxd@126.com (X.M.); YuefeiJia@shu.edu.cn (Y.J.) \\ * Correspondence: lipeiyou112@163.com; Tel./Fax: +86-0916-2641711
}

Received: 12 September 2019; Accepted: 18 October 2019; Published: 23 October 2019 updates

\begin{abstract}
The microstructure and mechanical properties of rapidly solidified $\beta$-type Ti-Fe-Sn-Mo alloys with high specific strength and low elastic modulus were investigated. The results show that the phases of Ti-Fe-Sn-Mo alloys are composed of the $\beta$-Ti, $\alpha-\mathrm{Ti}$, and TiFe phases; the volume fraction of TiFe phase decreases with the increase of Mo content. The high Fe content results in the deposition of TiFe phase along the grain boundary of the Ti phase. The $\mathrm{Ti}_{75} \mathrm{Fe}_{19} \mathrm{Sn}_{5} \mathrm{Mo}_{1}$ alloy exhibits the high yield strength, maximum compressive strength, large plastic deformation, high specific strength, high Vickers hardness, and large toughness value, which is a superior new engineering material. The elastic modulus ( $42.1 \mathrm{GPa}$ ) of $\mathrm{Ti}_{75} \mathrm{Fe}_{15} \mathrm{Sn}_{5} \mathrm{Mo}_{5}$ alloy is very close to the elastic modulus of human bone (10-30 GPa), which indicating that the alloy can be used as a good biomedical alloy. In addition, the large $H / E_{\mathrm{r}}$ and $H^{3} / E_{\mathrm{r}}{ }^{2}$ values of $\mathrm{Ti}_{75} \mathrm{Fe}_{19} \mathrm{Sn}_{5} \mathrm{Mo}_{1}$ alloy indicate the good wear resistance and long service life as biomedical materials.
\end{abstract}

Keywords: Ti-Fe-Sn-Mo alloys; mechanical properties; specific strength; elastic modulus

\section{Introduction}

Ti alloys have been widely used in engineering structural materials and biomedical materials [1-5]. As engineering structural materials, Ti alloys have low density, high strength, and good corrosion resistance, and they are widely used in automotive, aerospace and other fields [1,4,5]. As biomedical materials, Ti alloys have good biocompatibility, low modulus of elasticity, and high ductility, and they are widely used in medical devices, hard tissue, and soft tissue implants [2,3,5-10]. Among Ti-based alloys, Ti-Fe-based alloys are favored by researchers of engineering materials, functional materials and biomedical alloys, based on high strength, low density, high specific strength, and low elastic modulus [11-15]. In early studies, Ti-Fe based alloys were generally selected in hypereutectic regions, such as the binary $\mathrm{Ti}_{65} \mathrm{Fe}_{35}$ hypereutectic alloy, which has high fracture strength and yield strength, and the plastic deformation can reach $6.7 \%$; the microstructures of $\mathrm{Ti}_{65} \mathrm{Fe}_{35}$ alloy are composed of $\beta$-Ti and a large number of TiFe phases [16]. When $\mathrm{Sn}$ is added to binary $\mathrm{Ti}_{65} \mathrm{Fe}_{35}$ alloy, the strength and ductility of alloys can be improved; the reason is that the addition of Sn controls the growth of dendrites and it reduces the length-scale of lamellar spacing [17]. For hypereutectic Ti-Fe alloys, the high content of brittle TiFe phase leads to the low ductility of the alloys. It is necessary to reduce the content of Fe to control the content of TiFe phase. Therefore, some researchers choose the $\mathrm{Ti}_{70.5} \mathrm{Fe}_{29.5}$ eutectic component as base alloy [15-18]. When the minor $\mathrm{Sn}$ and $\mathrm{Nb}$ elements are added into eutectic $\mathrm{Ti}_{70.5} \mathrm{Fe}_{29.5}$ alloy, the grain size is refined and the content of TiFe phase is further reduced, which can improve the 
strength and ductility of the Ti-Fe-based alloys [15-19]. For example, the $\left(\mathrm{Ti}_{0.705} \mathrm{Fe}_{0.295}\right)_{96.15} \mathrm{Sn}_{3.85}$ alloy exhibits high yield strength of $1794 \mathrm{MPa}$ and large plastic deformation of 9.6\% [15]; the ductility of the $\left(\mathrm{Ti}_{0.705} \mathrm{Fe}_{0.295}\right)_{93.15} \mathrm{Sn}_{3.85} \mathrm{Nb}_{3}$ alloy can be further improved [19].

The microstructures of the eutectic Ti-Fe-based alloys are composed of $\beta$-Ti and TiFe phase [15-19]. Although the content of TiFe phase for the eutectic Ti-Fe-based alloys is lower than that of TiFe phase for the hypereutectic Ti-Fe-based alloys, the content of TiFe phase for the former is still high, which affects the strength and ductility of the Ti-Fe-based alloy. Ternary Ti-Fe-Cu, Ti-Fe-Ta, and Ti-Fe-Co and quaternary $\mathrm{Ti}-\mathrm{Fe}-\mathrm{Sn}-\mathrm{Nb}$ hypoeutectic alloys have been reported to further reduce the content of TiFe phase [13,20-23]. The $\mathrm{Ti}_{94} \mathrm{Fe}_{3} \mathrm{Cu}_{3}$ alloy exhibits the high tensile strength (1200 MPa) and large percentage elongation of $9 \%$, which is attributed to the formation of micro/nano-structured $\alpha$ - and $\beta$-Ti phases by the dual-axial forging method [20]. The $\mathrm{Ti}_{80} \mathrm{Fe}_{14} \mathrm{Sn}_{3} \mathrm{Nb}_{3}$ alloy exhibits the high yield strength of $1.88 \mathrm{GPa}$, ultimate compressive stress of $2400 \mathrm{MPa}$, plastic strain of $32.4 \%$; the good mechanical properties are attributed to supersaturated $\beta$-Ti phase and the high density of lattice defects that restrict the dislocation motion [12].

The microstructures of hypoeutectic Ti-Fe-based alloys are generally composed of $\beta$-Ti and $\alpha$-Ti phases; the strength of the alloys is low and the ductility is high when the alloys are mainly composed of $\beta$-Ti phases. When the alloy is eutectic, the alloy is composed of a large number of $\beta$-Ti and TiFe phases. The plasticity of the alloy is low because of the high content of brittle TiFe phases. While the alloy is hypereutectic, the alloy is composed of a small number of $\beta$-Ti phases and a large number of TiFe phases, and the plasticity of the alloy is low. We have previously reported that $\mathrm{Ti}_{80} \mathrm{Fe}_{20}$ is a base alloy, the phase of which is composed of a combined $\beta$-Ti phase and a small amount of TiFe phases, and its strength is low. A small amount of Sn element is used to replace part of Ti element to improve the precipitation of TiFe phase. Among the reported rapidly solidified $\mathrm{Ti}_{79} \mathrm{Fe}_{20} \mathrm{Sn}_{1}, \mathrm{Ti}_{77} \mathrm{Fe}_{20} \mathrm{Sn}_{3}$, and $\mathrm{Ti}_{75} \mathrm{Fe}_{20} \mathrm{Sn}_{5}$ alloys, the $\mathrm{Ti}_{75} \mathrm{Fe}_{20} \mathrm{Sn}_{5}$ alloy has the lowest elastic modulus, the highest yield strength, and plastic deformation [11]. In fact, rapid solidification is a faster cooling method than natural cooling rate. The alloy that was prepared by rapid solidification had the small particle size. According to Hall-petch expression, when the alloy has smaller particle size, the strength of the alloy is larger $[11,12,14]$. It is necessary to reduce the content of brittle TiFe phase and prepare alloys by rapid solidification to further improve the strength and plasticity of $\mathrm{Ti}_{75} \mathrm{Fe}_{20} \mathrm{Sn}_{5}$ alloy. In this paper, the effect of Mo addition on the microstructure and mechanical properties of rapidly solidified Ti-Fe-Sn-Mo quaternary alloys was studied by replacing the Fe element with minor Mo element. The experimental data obtained can be used as reference for engineering application and biomaterial application.

\section{Experimental Procedure}

Various combinations of pure $\mathrm{Ti}, \mathrm{Fe}, \mathrm{Sn}$, and Mo (purity of $99.9 \%$ or higher) were used to prepare the ingots of three Ti-Fe-Sn-Mo alloys with nominal compositions of $\mathrm{Ti}_{75} \mathrm{Fe}_{19} \mathrm{Sn}_{5} \mathrm{Mo}_{1}, \mathrm{Ti}_{75} \mathrm{Fe}_{17} \mathrm{Sn}_{5} \mathrm{Mo}_{3}$, and $\mathrm{Ti}_{75} \mathrm{Fe}_{15} \mathrm{Sn}_{5} \mathrm{Mo}_{5}$ (at.\%) under a high vacuum $\left(3 \times 10^{-3} \mathrm{~Pa}\right)$ while using a magnetically controlled tungsten arc-melting furnace (Shenyang Scientific Instruments Co., Ltd., Chinese Academy of Sciences, Shenyang, China) in high purity argon atmosphere. The raw materials $\mathrm{Ti}, \mathrm{Fe}$, and $\mathrm{Sn}$ are bulk, and the range of sizes was from $5 \times 5 \times 5 \mathrm{~mm}^{3}$ to $20 \times 20 \times 20 \mathrm{~mm}^{3}$. These raw materials were obtained from Beijing Xingrongyuan Technology Co., Ltd. (Beijing, China). As the high melting point of Mo, the number of melting times of ingots is more than five times in arc melting to ensure the chemical homogeneity of the components. As the low melting point of Sn, in the first melting process, Sn blocks were placed at the bottom of the melting crucible. The other three alloys were covered with Sn blocks to reduce the volatilization of molten Sn elements. Subsequently, the melted alloy ingot was melted again in the suction crucible and then filled with copper mould to make the cylindrical bar with diameter of $3 \mathrm{~mm}$ and length of $50 \mathrm{~mm}$. Slow-speed metal saw was used to cut the samples needed for the test of microstructure and mechanical properties from $3 \mathrm{~mm}$ rod-like samples. The microstructure of samples with the diameter of $3 \mathrm{~mm}$ was characterized while using a Rigaku $\mathrm{D} \backslash$ max-2550 X-ray diffractometer (XRD, Rigaku Company, Tokyo, Japan) with Cu Ka radiation, using the operating voltage is $30 \mathrm{KV}$. 
Standard metallographic techniques, consisting of grinding up to 2000 grit with a SiC paper and polishing with a colloidal silica suspension, were used on the surface of $3 \mathrm{~mm}$ specimens to observe the microstructure of the samples. The surfaces of polished samples need to be etched for observing the microstructure. This was accomplished with a mixed solution of $\mathrm{HF}, \mathrm{HNO}_{3}$, and $\mathrm{H}_{2} \mathrm{O}$, and the corresponding volume ratio is 1:4:5. The microstructure of prepared samples was observed by optics microscope (OM, Shanghai Changfang Optical Instrument Co., LTD, Shanghai, China).

The Ti-Fe-Sn-Mo samples with a diameter of $3.0 \mathrm{~mm}$ and height of $\sim 5.0 \mathrm{~mm}$ were prepared by subjecting to quasi-static uniaxial compression testing at room temperature, while using a CMT5105 electronic testing machine (Metis Industrial Systems (China) Co., Ltd., Shanghai, China). The strain rate is $2.5 \times 10^{-4} \mathrm{~s}^{-1}$. The two ends of the sample need to be parallel and smooth to reduce the friction between the cross section of the sample and the pressure head of the instrument. The fracture morphology of the compressed samples was observed by scanning electron microscopy (SEM, JSM-6390LV, JEOL, Peabody, MA, USA) with an energy dispersive spectrometer (EDS). The two ends of the sample need to be parallel and the testing end needs to be smooth to accurately test the Vickers hardness of the sample. Therefore, the Vickers hardness of polished samples was tested while using an HVS-10Z/LCD hardness testing machine (Shanghai Gaozhi Precision Instrument Co., Ltd., Shanghai, China). During the test, the loading force is $200 \mathrm{~N}$ and the holding time is $10 \mathrm{~s}$. The densities of samples $(\rho)$ were measured by Archimedes method while using ZMD electrinic density meter.

The microstructures of the samples were observed by transmission electron microscope (TEM) and the samples with thickness of 300-500 $\mu \mathrm{m}$ were cut from as-cast samples. Subsequently, the 800, 1000, 1200 , and 2000 grits with the SiC papers were used to manually grind the sample to approximately $50 \mu \mathrm{m}$. The disks were then electropolished using a twin-jet method in an electrolyte solution of $25 \% \mathrm{HNO}_{3}$ and $75 \%$ methanol by volume around $238 \mathrm{~K}$. TEM measurements were carried out using a JEM-2100F microscope with an accelerating voltage of $200 \mathrm{kV}$.

The elastic modulus and hardness of Ti-Fe-Sn-Mo alloys were measured by the nano-indentation technique. The nano-indentation tests were performed by a Hystron-T1900 TriboIndentor system (Beijing Obel Scientific Instruments Co., Ltd. Beijing, China) that was equipped with a Berkovich indenter (Bruker, Germany). During the nono-indentation test, the loading force is $8000 \mu \mathrm{N}$, the loading and unloading rates are $1.6 \mathrm{mN} \cdot \mathrm{s}^{-1}$, and the loading time, holding time, and unloading time are $5 \mathrm{~s}$. Nanoindentation tests are measured at least 10 times and the reported data are the average of 10 times to reduce the test error. The reduced elastic modulus $\left(E_{\mathrm{r}}\right)$ and hardness $(H)$ values were automatically calculated using the TriboScan ${ }^{\mathrm{Tm}}$ software (Boston University, Massachusetts, USA). To ensure the correctness of the measured results, the surface of each sample was polished to mirror-finish. Based on a Berkovich indenter, the calculated $E_{\mathrm{r}}$ values were used [24]:

$$
E_{\mathrm{r}}=\frac{\sqrt{\pi}}{2 \sqrt{A\left(h_{\mathrm{c}}\right)}} S
$$

where $S$ is the stiffness and $A\left(h_{\mathrm{c}}\right)$ represents the contact area. In addition, the relationship between the $E_{\mathrm{r}}$ and standard elastic modulus $\left(E_{\mathrm{s}}\right)$ is as follows [25],

$$
\frac{1}{E_{\mathrm{r}}}=\frac{1-v_{\mathrm{s}}^{2}}{E_{\mathrm{s}}}+\frac{1-v_{\mathrm{i}}^{2}}{E_{\mathrm{i}}}
$$

where $v_{\mathrm{S}}$ and $v_{\mathrm{i}}$ are the Poisson's ratio of the sample and indenter, respectively. For the Ti-based biomedical alloys, the average value of $v_{\mathrm{s}}$ is equal to 0.36 [26]. 


\section{Results and Discussion}

\subsection{Microstructure of Ti-Fe-Sn-Mo Alloys}

Figure 1 shows the XRD patterns of the Ti-Fe-Sn-Mo alloys. The results show that the phases of the $\mathrm{Ti}_{75} \mathrm{Fe}_{19} \mathrm{Sn}_{5} \mathrm{Mo}_{1}, \mathrm{Ti}_{75} \mathrm{Fe}_{17} \mathrm{Sn}_{5} \mathrm{Mo}_{3}$, and $\mathrm{Ti}_{75} \mathrm{Fe}_{15} \mathrm{Sn}_{5} \mathrm{Mo}_{5}$ alloys are composed of $\beta-\mathrm{Ti}, \alpha-\mathrm{Ti}$, and TiFe phases, which indicates that the addition of Mo does not change the types of phases of the alloys. At the same test conditions in XRD patterns, the relative diffraction intensity of a phase can approximately reflect the volume fraction of the corresponding phase [2]. The relative diffraction intensity of TiFe phase decreases with the increase of Mo content in Figure 1a, indicating that the volume fraction of TiFe phase decreases with the increase of Mo content. As the differences of diffraction angle for the strongest diffraction peak between the $\beta$-Ti and $\alpha$-Ti phases are small, Figure $1 \mathrm{~b}$ is a local magnification diagram of Figure 1a, to distinguish the diffraction peaks of the two phases. In Figure 1b, the strongest diffraction peak of the $\mathrm{Ti}_{75} \mathrm{Fe}_{19} \mathrm{Sn}_{5} \mathrm{Mo}_{1}$ alloy is the $\alpha$-Ti phase, while the intensity of the $\beta$-Ti phase is lower than that of the $\alpha$-Ti phase, which indicates that the matrix phase of the alloy is $\alpha$-Ti phase, and the second phases are the $\beta-\mathrm{Ti}$ and TiFe phases. In fact, this result is consistent with the type of matrix phase and the second phase of $\mathrm{Ti}_{75} \mathrm{Fe}_{20} \mathrm{Sn}_{5}$ alloy [11], which suggests that the addition of minor Mo does not change the type of phase. For the $\mathrm{Ti}_{75} \mathrm{Fe}_{17} \mathrm{Sn}_{5} \mathrm{Mo}_{3}$ alloy, the strongest diffraction peak is $\beta$-Ti phase, while the diffractive strength of $\alpha$-Ti phase is smaller than that of $\alpha$-Ti phase for the $\mathrm{Ti}_{75} \mathrm{Fe}_{19} \mathrm{Sn}_{5} \mathrm{Mo}_{1}$ alloy, indicating that the matrix phase of the $\mathrm{Ti}_{75} \mathrm{Fe}_{17} \mathrm{Sn}_{5} \mathrm{Mo}_{3}$ alloy is the $\beta$-Ti phase and the second phase is the $\alpha-\mathrm{Ti}$ and TiFe phases. Accordingly, that the addition of Mo changes the matrix phase and the second phase of $\mathrm{Ti}_{75} \mathrm{Fe}_{20} \mathrm{Sn}_{5}$ alloy. In addition, for the $\mathrm{Ti}_{75} \mathrm{Fe}_{15} \mathrm{Sn}_{5} \mathrm{Mo}_{5}$ alloy, the strongest diffraction peak is the $\alpha$-Ti phase, while the intensity of diffraction peak of the $\beta$-Ti phase is lower than that of the $\alpha$-phase, which indicates that the matrix phase of the alloy is the $\alpha$-Ti phase and the second phase is the $\beta$-Ti phase and TiFe phase. Thus, the matrix phase of the $\mathrm{Ti}_{75} \mathrm{Fe}_{19} \mathrm{Sn}_{5} \mathrm{Mo}_{1}$ and $\mathrm{Ti}_{75} \mathrm{Fe}_{15} \mathrm{Sn}_{5} \mathrm{Mo}_{5}$ alloys is the $\alpha$-Ti phase, the second phases are the $\beta$-Ti and TiFe phases, while the matrix phase of $\mathrm{Ti}_{75} \mathrm{Fe}_{17} \mathrm{Sn}_{5} \mathrm{Mo}_{5}$ alloy is the $\beta$-Ti phase, and the second phases are the $\alpha$-Ti and TiFe phases.
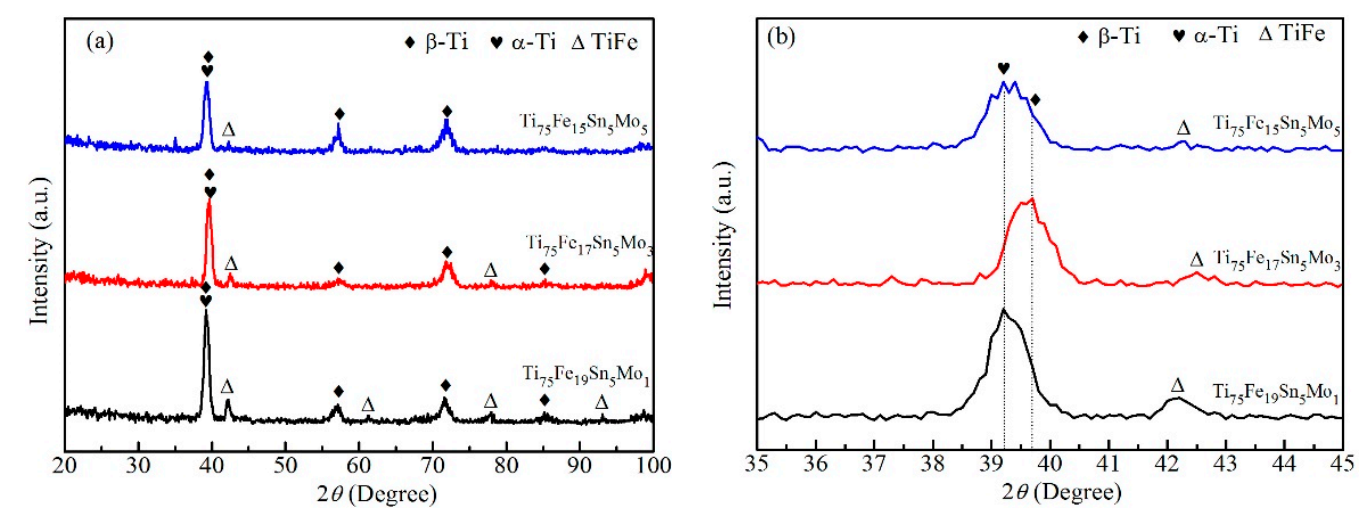

Figure 1. X-ray diffractometer (XRD) patterns of the Ti-Fe-Sn-Mo alloys. (a) $20^{\circ}-100^{\circ}$; (b) $35^{\circ}-45^{\circ}$.

In fact, in the XRD patterns, the approximate volume fraction of the corresponding phase can be calculated based on the relative diffraction intensity of the phase [2,11]. When the strong diffraction intensity of phase is normalized to $100 \%$, and the strong diffraction intensities of the other phases are normalized, the normalized value can approximately represent the relative volume fraction $\left(V_{r i}\right)$ of each phase [11]. The relationship between the $V_{r i}$ values and the approximate volume fraction $\left(V_{1}\right)$ of phase with strong diffraction intensity can be written by [11],

$$
\sum_{i=1}^{n} V_{1} V_{r i}=100 \%(i=1,2,3, \ldots, n)
$$


and

$$
V_{i}=V_{1} V_{r i}(i=1,2,3, \ldots, n)
$$

$V_{i}$ is the approximate volume fraction of the $i$ phase. Table 1 lists the approximate volume fractions of $\beta$-Ti phase, $\alpha$-Ti phase, and TiFe phase calculated from Figure 1. For the $\mathrm{Ti}_{75} \mathrm{Fe}_{19} \mathrm{Sn}_{5} \mathrm{Mo}_{1}$ alloy, the $V_{\beta}$ value of $\beta$-Ti phase is $42.3 \%$, that of $\alpha$-Ti phase is $47.3 \%$, and the difference of volume fraction between the two phases is small. For the $\mathrm{Ti}_{75} \mathrm{Fe}_{17} \mathrm{Sn}_{5} \mathrm{Mo}_{3}$ alloy, the volume fractions of the $\beta$-Ti and $\alpha$-Ti phases are $56.8 \%$ and $33.4 \%$, respectively, indicating that the difference of volume fraction between the two phases is large. For the $\mathrm{Ti}_{75} \mathrm{Fe}_{15} \mathrm{Sn}_{5} \mathrm{Mo}_{5}$ alloy, the $V_{\alpha}$ of the $\alpha$-Ti phase is as high as $60 \%$, which is the largest of the three alloys, while the $V_{\beta}$ value of the $\beta$-Ti phase is $37.8 \%$, which is the smallest of the three alloys, and the volume difference between the two phases is quite different. In addition, the volume fraction of TiFe phase decreases from $10.4 \%$ of $\mathrm{Ti}_{75} \mathrm{Fe}_{19} \mathrm{Sn}_{5} \mathrm{Mo}_{1}$ alloy to $2.2 \%$ of the $\mathrm{Ti}_{75} \mathrm{Fe}_{15} \mathrm{Sn}_{5} \mathrm{Mo}_{5}$ alloy, which indicates that the volume fraction of TiFe phase decreases with the increase of Mo content. In fact, the volume fraction of TiFe phase in the $\mathrm{Ti}_{75} \mathrm{Fe}_{19} \mathrm{Sn}_{5} \mathrm{Mo}_{1}$ alloy is less than that of TiFe phase in $\mathrm{Ti}_{75} \mathrm{Fe}_{20} \mathrm{Sn}_{5}$ alloy (11.31\%) [11], which indicates the increase of Mo content and the decrease of Fe content resulting in less volume fraction of TiFe phase. The Rietveld method was used to calculate the volume fractions $\left(V_{R}\right)$ of three phases to show the accuracy of phase volume fraction calculated in Ref. [11]. For the $\mathrm{Ti}_{75} \mathrm{Fe}_{19} \mathrm{Sn}_{5} \mathrm{Mo}_{1}$ alloy, the $V_{\mathrm{R}}$ values of $\beta$-Ti, $\alpha$-Ti and TiFe phases are $43.92 \%, 47.66 \%$, and $8.42 \%$, respectively; for the $\mathrm{Ti}_{75} \mathrm{Fe}_{17} \mathrm{Sn}_{5} \mathrm{Mo}_{3}$ alloy, the corresponding $V_{\mathrm{R}}$ values of three phases are $59.67 \%, 33.42 \%$, and $7.91 \%$, respectively; for the $\mathrm{Ti}_{75} \mathrm{Fe}_{15} \mathrm{Sn}_{5} \mathrm{Mo}_{5}$ alloy, the $V_{\mathrm{R}}$ values of three phases are $39.30 \%, 57.56 \%$, and $3.14 \%$, respectively. Therefore, the volume fractions of the three phases calculated by Equations (3) and (4) are close to the $V_{\mathrm{R}}$ values that were calculated by the Rietveld method.

Table 1. Mechanical properties of Ti-Fe-Sn-Mo alloys, including linear elastic limit $\left(\sigma_{\mathrm{e}}\right)$, the $0.2 \%$ offset yield stress $\left(\sigma_{0.2}\right)$, true plastic strain $\left(\varepsilon_{\mathrm{p}}\right)$, maximum compression strength $\left(\sigma_{\mathrm{b}}\right)$, elastic energy $\left(W_{\mathrm{e}}\right)$, toughness values $\left(A_{\mathrm{t}}\right)$, approximate volume fraction of phase $(V)$, Vickers hardness $(\mathrm{HV})$, and elastic modulus $(E)$ in quasi-static compression test.

\begin{tabular}{|c|c|c|c|c|c|c|c|c|c|c|c|}
\hline Alloys & $\sigma_{\mathrm{e}}$ & $\sigma_{0.2}$ & $\varepsilon_{\mathrm{p}}$ & $\sigma_{\mathrm{b}}$ & $W_{\mathrm{e}} \times 10^{6}$ & $A_{\mathrm{t}} \times 10^{6}$ & $V_{\beta-\mathrm{Ti}}$ & $V_{\alpha-\mathrm{Ti}}$ & $V_{\text {TiFe }}$ & HV & $E$ \\
\hline $\mathrm{Ti}_{75} \mathrm{Fe}_{19} \mathrm{Sn}_{5} \mathrm{Mo}_{1}$ & 1502 & 1734 & 16.1 & 2590 & 13.36 & 383.14 & 42.3 & 47.3 & 10.4 & 590 & 85.4 \\
\hline $\mathrm{Ti}_{75} \mathrm{Fe}_{15} \mathrm{Sn}_{5} \mathrm{Mo}_{5}$ & 1407 & 1496 & 3.5 & 1683 & 30.3 & 85.7 & 37.8 & 60 & 2.2 & 534 & 33.4 \\
\hline
\end{tabular}

Figure 2 shows the microstructure of the Ti-Fe-Sn-Mo alloys. In Figure 2a,b, for the $\mathrm{Ti}_{75} \mathrm{Fe}_{19} \mathrm{Sn}_{5} \mathrm{Mo}_{1}$ alloy, a large number of $\alpha$-Ti phases and a small amount of TiFe phases are deposited along the grain boundary, and the part of the $\alpha$-Ti phase is formed inside the $\beta$-Ti phase particles. In Figure $2 a, b$, the contents of $\alpha$-Ti phase and $\beta$-Ti phase have little difference, which is in good agreement with the volume fraction that was calculated by XRD. For the $\mathrm{Ti}_{75} \mathrm{Fe}_{17} \mathrm{Sn}_{5} \mathrm{Mo}_{3}$ alloy, the content of $\beta$-Ti phase is obviously higher than that of $\alpha$-Ti phase, as shown in Figure 2c,d, which is in good agreement with the volume difference of the two phases that were calculated by XRD in Table 1; in addition, a large number of $\alpha$-Ti phases are mainly deposited along grain boundary. In fact, the contents of $\alpha$-Ti phase deposited inside the $\beta$-Ti phase particles in Figure $2 \mathrm{~d}$ are obviously lower than those of $\alpha$-Ti phase deposited inside $\beta$-Ti phase particles in Figure $2 \mathrm{~b}$. The particle sizes of a small amount of TiFe phases for the $\mathrm{Ti}_{75} \mathrm{Fe}_{17} \mathrm{Sn}_{5} \mathrm{Mo}_{3}$ alloy are obviously larger than those of the TiFe phases for the $\mathrm{Ti}_{75} \mathrm{Fe}_{19} \mathrm{Sn}_{5} \mathrm{Mo}_{1}$ alloy, as shown in Figure $2 \mathrm{~b}, \mathrm{~d}$, but the numbers of particles of the TiFe phases in the former are significantly less than those of the TiFe phases in the latter. As a result, the difference of content of TiFe phase between the two alloys is small, which is consistent with the small difference of volume fraction calculated by XRD in Table 1. With a further increase in Mo content and a further decrease in $\mathrm{Fe}$ content, for the $\mathrm{Ti}_{75} \mathrm{Fe}_{15} \mathrm{Sn}_{5} \mathrm{Mo}_{5}$ alloy, only two particles of TiFe phase labeled with the black arrow in Figure 2e,f can be observed. Its content is obviously smaller than that of TiFe phase in 
Figure $2 b, e$, which is also consistent with the small volume fraction of the TiFe phase that was calculated by XRD in Table 1 . The content of $\beta$-Ti phase in $\mathrm{Ti}_{75} \mathrm{Fe}_{15} \mathrm{Sn}_{5} \mathrm{Mo}_{5}$ alloy is obviously lower than those in $\mathrm{Ti}_{75} \mathrm{Fe}_{19} \mathrm{Sn}_{5} \mathrm{Mo}_{1}$ and $\mathrm{Ti}_{75} \mathrm{Fe}_{17} \mathrm{Sn}_{5} \mathrm{Mo}_{3}$ alloys, and the content of $\alpha$-Ti phase in $\mathrm{Ti}_{75} \mathrm{Fe}_{15} \mathrm{Sn}_{5} \mathrm{Mo}_{5}$ alloy is higher than that in $\mathrm{Ti}_{75} \mathrm{Fe}_{19} \mathrm{Sn}_{5} \mathrm{Mo}_{1}$ and $\mathrm{Ti}_{75} \mathrm{Fe}_{17} \mathrm{Sn}_{5} \mathrm{Mo}_{3}$ alloys, as shown in Figure $2 \mathrm{~b}, \mathrm{~d}$,f. Accordingly, these results are consistent with the calculated data in Table 1.
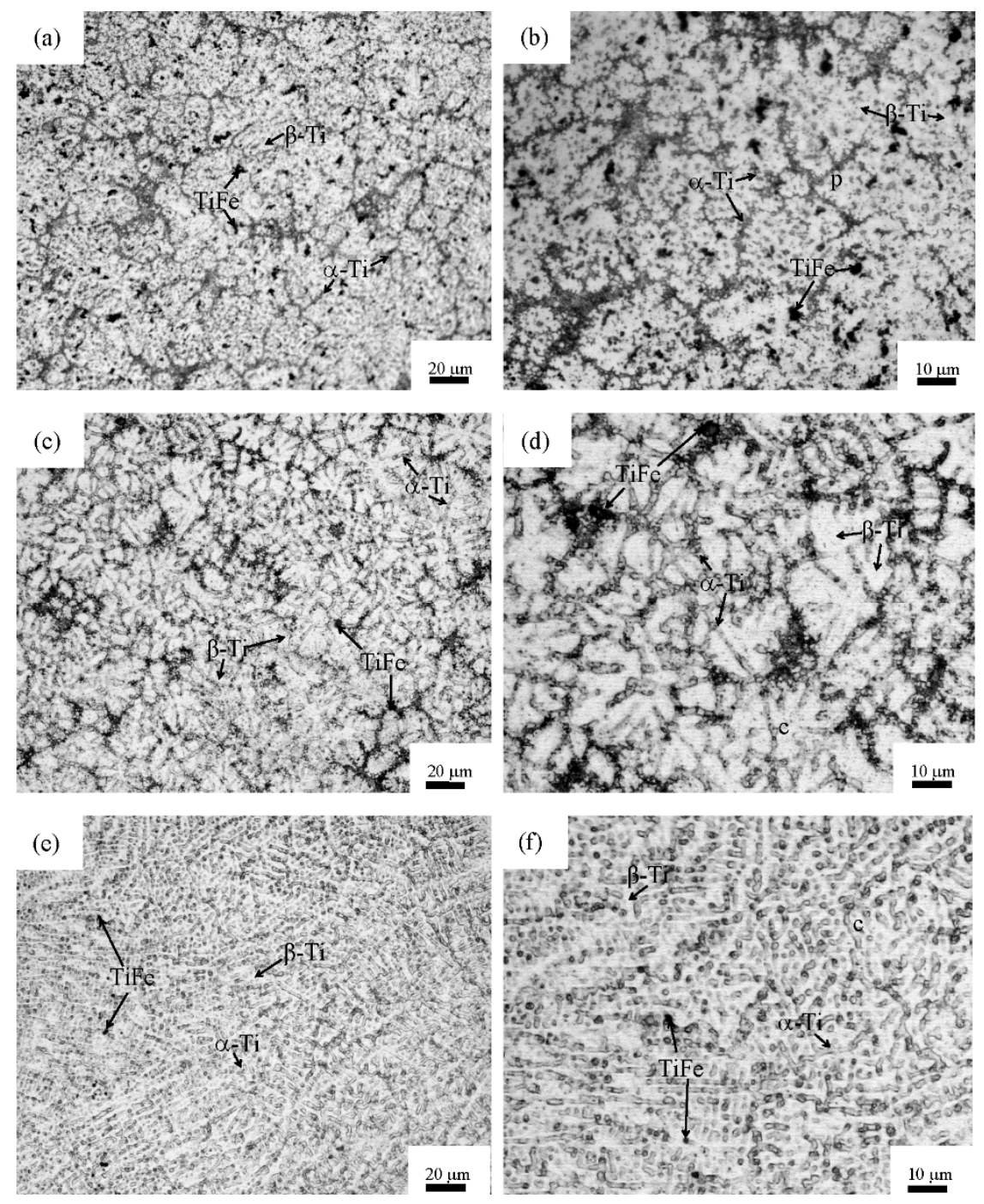

Figure 2. Microstructure of the (a,b) $\mathrm{Ti}_{75} \mathrm{Fe}_{19} \mathrm{Sn}_{5} \mathrm{Mo}_{1},(\mathbf{c}, \mathbf{d}) \mathrm{Ti}_{75} \mathrm{Fe}_{17} \mathrm{Sn}_{5} \mathrm{Mo}_{3},(\mathbf{e}, \mathbf{f}) \mathrm{Ti}_{75} \mathrm{Fe}_{15} \mathrm{Sn}_{5} \mathrm{Mo}_{5}$ alloys.

At the grain boundary, the $\alpha$-Ti phases of the $\mathrm{Ti}_{75} \mathrm{Fe}_{19} \mathrm{Sn}_{5} \mathrm{Mo}_{1}$ alloy in Figure $2 \mathrm{~b}$ form the structure of continuous layers; however, in addition to the continuous layer, the discontinuous layers in $\mathrm{Ti}_{75} \mathrm{Fe}_{17} \mathrm{Sn}_{5} \mathrm{Mo}_{3}$ alloy are also found in Figure $2 \mathrm{~d}$, which indicated that the continuity of the $\alpha$-Ti phase are weakened when comparing with the continuous layers in $\mathrm{Ti}_{75} \mathrm{Fe}_{19} \mathrm{Sn}_{5} \mathrm{Mo}_{1}$ alloy. The continuity of the $\alpha$-Ti phase for the $\mathrm{Ti}_{75} \mathrm{Fe}_{15} \mathrm{Sn}_{5} \mathrm{Mo}_{5}$ alloy almost disappears in Figure $2 \mathrm{f}$. A large number of discontinuous independent grains of the $\alpha$-Ti phase can be observed in Figure $2 \mathrm{f}$. The phenomenon can be explained by using the grain boundary wetting $[27,28]$. In the reported Ti-Fe, Ti-Co, Ti-Fe-Sn alloys, the continuous and discontinuous layers that are composed of the $\alpha$-Ti phases are the complete and non-complete wetting of the grain boundary $[11,27,28]$, respectively. In Figure $2 b$, the continuous layer that is formed by a large number of $\alpha$-Ti phases at the boundary is the complete wetting of the gain boundary, as shown in the letter P in Figure $2 b$. In Figure $2 d$, the continuous and discontinuous layers observed are the phenomenon of the complete and incomplete wetting of grain boundary. A large number of discontinuous layer of $\alpha$-Ti phases show a structural of incomplete wetting, as shown in the 
letter $\mathrm{C}$ in Figure 2f. Accordingly, adding tge Mo element can change the complete and incomplete wetting of grain boundary.

The content of TiFe phase can be qualitatively discussed by heat of mixing $\left(\Delta H_{\mathrm{x}}\right)$ between mail elements. Table 2 lists the $\Delta H_{\mathrm{x}}$ values among the four elements. As the large negative heat of mixing between atom pairs indicates that the interaction force of atom pairs is larger, it can promote the formation of stable intermetallic compound. However, the small negative heat of mixing or large positive heat of mixing indicates that the interaction force of atom pair is weak. The melt that is composed of two elements is easy to form solid solution during cooling. The $\Delta H_{\mathrm{x}}$ values of Ti-Fe $\left(-17 \mathrm{~kJ} \mathrm{~mol}^{-1}\right.$ [29]) and Ti-Sn $\left(-21 \mathrm{~kJ} \mathrm{~mol}^{-1}\right.$ [29]) atom pairs are larger than those of the Ti-Mo $\left(-4 \mathrm{~kJ} \mathrm{~mol}^{-1}\right.$ [29]) and $\mathrm{Fe}-\mathrm{Mo}\left(-2 \mathrm{~kJ} \mathrm{~mol}^{-1}\right.$ [29]) atomic pairs, which indicates that the interaction forces of Ti-Fe and Ti-Sn atom pairs are larger than those of the Ti-Mo and Fe-Mo atomic pairs. The melt containing Ti-Mo and Fe-Mo clusters can form solid solution during cooling. In addition, the interaction forces of Fe-Sn and Mo-Sn atom pairs are weak, and the solid solution is easy to form in the alloy solution during the cooling due to the positive heat of mixing of $\mathrm{Fe}-\mathrm{Sn}$ and $\mathrm{Sn}$-Mo atom pairs (see Table 1). Therefore, when a small amount of Mo element replaces Fe element, no intermetallic compound containing Mo element can form. The addition of Mo changes the concentration of clusters containing Fe in alloy solution, which results the content of TiFe intermetallics decreasing. In addition, the more the Mo content is, the less the TiFe phase intermetallic compounds precipitate. This is consistent with the volume fraction that was calculated by XRD.

Table 2. Heat of mixing of Ti-Fe-Sn-Mo Alloys.

\begin{tabular}{|c|c|c|c|c|}
\hline \multirow{2}{*}{ Elements } & \multicolumn{4}{|c|}{ Heat of mixing $\left(\mathrm{kJ} \cdot \mathrm{mol}^{-1}\right)$ [29] } \\
\hline & $\mathrm{Ti}$ & $\mathrm{Fe}$ & Sn & Mo \\
\hline $\mathrm{Ti}$ & 0 & -17 & -21 & -4 \\
\hline $\mathrm{Fe}$ & - & 0 & 11 & -2 \\
\hline Sn & - & - & 0 & 20 \\
\hline Mo & - & - & - & 0 \\
\hline
\end{tabular}

Figure 3 shows the SEM picture, element content at each point scanning, and surface distribution of elements at surface scanning in $\mathrm{Ti}_{75} \mathrm{Fe}_{19} \mathrm{Sn}_{5} \mathrm{Mo}_{1}$ alloy. In Figure $3 \mathrm{a}$, five dot scanned images are marked as P1, P2, P3, P4, and P5, respectively. The percentages of four elements of five spots are shown in the right border of Figure 3a. The region that is labeled P1 is the middle part of a complete grain. The composition of the grain is $\mathrm{Ti}_{79.35} \mathrm{Fe}_{10.16} \mathrm{Sn}_{8.25} \mathrm{Mo}_{2.24}$. In fact, the grain in the region labeled P1 is a particle mainly containing the $\beta$-Ti phase in Figure $2 a, b$; for the particle containing Ti phase, according to EDS analysis, the contents of Ti, Sn, and Mo elements are larger than those of Ti, Sn, and Mo elements in $\mathrm{Ti}_{75} \mathrm{Fe}_{19} \mathrm{Sn}_{5} \mathrm{Mo}_{1}$ nominal component. When point scanning was carried out at the boundary of $\beta$-Ti particles (P3), it is found that the Ti (78.01 at.\%), Sn (5.71 at.\%), and Mo (1.76 at.\%) contents in the region labeled P3 are lower than the corresponding contents in region labeled P1, but the Fe content (P3) is larger than that (P1). The results show that the content of Fe in the grain is less, while the content of Fe increases near the grain boundary, and the contents of Sn and Mo correspondingly decrease at the grain boundary. When point scanning was carried out at grain boundary (P2), the contents of Ti, $\mathrm{Fe}$, Sn and Mo elements are 70.74 at.\%, 26.47 at. \%, 2.33 at.\%, and 0.46 at.\%, respectively. It is found that the contents of Ti, Sn, and Mo at the P2 region were significantly smaller than those at the P1 and P3 regions, while the contents of Fe at the P2 region are significantly larger than those at the P1 and P3 regions. According to Figure 2a,b, the larger black particles at the boundary are TiFe phase, and TiFe phase deposits along the grain boundary. In fact, it is impossible for the quantitative analysis of elements in the region labeled P2 point to achieve or close to one-to-one atomic ratio of Ti and Fe for the TiFe phase, as the accuracy of quantitative analysis for the elements by point scanning of EDS is low. The point scanning of the regions labeled P4 and P5 at grain boundaries was carried out to better determine the enrichment of Fe elements at grain boundaries. The Ti and Fe contents at regions 
labeled P4 and P5 slightly differ. At the region labeled P5, Sn content is significantly lower than that at regions of grain boundary labeled P2, and also lower that that at the region of grain interior labeled P1. When the Sn-rich region appears at region labeled P1, the Sn-poor region will inevitably appear around it to reach the equilibrium state of $\mathrm{Sn}$ content for the whole alloy. Five-point scanning shows that the Sn content is low when the Fe content is high. This is because the heat of mixing of Fe and Sn is positive. In the process of melt cooling, the repulsion force of Fe and Sn atoms is larger than the attraction force, which results in the diffusion of Fe and Sn atoms in the opposite direction.
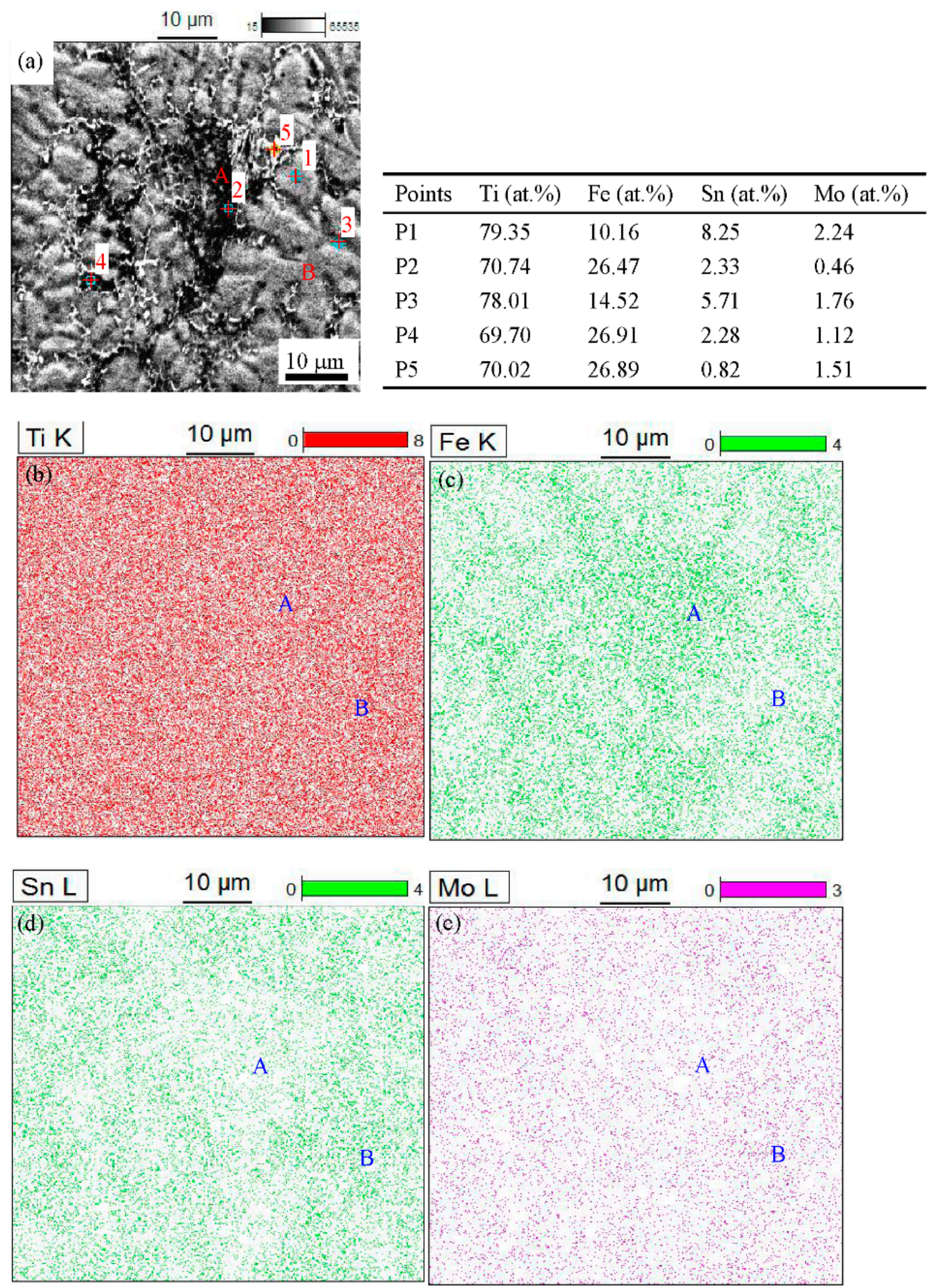

Figure 3. Energy dispersive spectrometer (EDS) pictures of $\mathrm{Ti}_{75} \mathrm{Fe}_{19} \mathrm{Sn}_{5} \mathrm{Mo}_{1}$ alloy. (a) Scanning electron microscopy (SEM) picture and element content at each point scanning; (b-e) surface distribution of elements at place scanning. 
Figure $3 \mathrm{a}$ is scanned in a plane to observe the difference between Fe- and Sn-rich regions more directly. The distribution of four elements is shown in Figure 3b-e. As the alloy is Ti-rich alloy, there is no obvious difference in the distribution of Ti element in the whole region, while the other three elements show the Fe-, Sn-, and Mo-rich regions, and Fe, Sn, and Mo-poor regions. In Figure 3a, the regions labeled A and B are selected. The large particle containing TiFe phase locates in A region, and the large particle containing Ti phase locates in B region. In Figure 3c, the Fe content in A region is significantly larger than that in B region. In Figure 3d, the Sn content in A region is significantly lower than that in the B region. Therefore, most Sn and Mo elements are in Ti-containing particles, respectively. The attraction between Ti and Sn atomic pairs is larger than the repulsion, as the heat of mixing of Ti and $\mathrm{Sn}$ is $-21 \mathrm{~kJ} \mathrm{~mol}^{-1}$ [29], so the cluster containing the Ti-Sn atomic pair is easy to form. The mutual repulsion force between $\mathrm{Fe}$ and $\mathrm{Sn}$ is larger than the mutual attraction because of the positive heat of mixing of $\mathrm{Sn}$ and Fe, which leads to the decrease of Fe content in the Sn-rich region. Because the heat of mixing of Ti and Fe atomic pair is $-17 \mathrm{~kJ} \mathrm{~mol}^{-1}$ [29], the binding force of $\mathrm{Ti}$ and $\mathrm{Fe}$ atoms is larger than the repulsion force of Ti-Fe atom pair, which leads to the formation of clusters containing Ti-Fe atomic pair; in this region, the content of $S n$ is less. Therefore, TiFe phases in Fe-rich regions and Ti phases in Sn-rich regions are formed in different regions. Although Ti content higher, the $\mathrm{Sn}$ content is less, so the $\mathrm{Ti}_{3} \mathrm{Sn}$ phase is difficult to form. The atomic ratio of Ti to Fe is located in hypoeutectic region, and the high Fe content results in the deposition of TiFe phase along the grain boundary of Ti phase.

The microstructure of $\mathrm{Ti}_{75} \mathrm{Fe}_{19} \mathrm{Sn}_{5} \mathrm{Mo}_{1}$ alloy was observed by TEM to further understand of the microstructure and phase composition of the Ti-Fe-Sn-Mo alloys, as shown in Figure 4. Figure 4a,c show the stripe grain with a width between $0.1 \mu \mathrm{m}$ and $0.2 \mu \mathrm{m}$ and the black massive grains. The selected electron diffraction spots of the strip grains calibrate the diffraction spots that were obtained. Combining with the analysis of phases in XRD, the gray stripe grain is $\alpha$-Ti phase, and the black block grain is TiFe phase, as shown in Figure $4 a$,c. The diffraction spots of Figure $4 b$ come from the labeled " $\mathrm{A}$ " region in Figure 3a, the calibrated crystal band axis of the $\alpha$-Ti phase is [2110], the crystal planes $(000 \overline{1}),(0 \overline{1} 10)$, and $(0 \overline{1} 1 \overline{1})$ are also marked in Figure $4 \mathrm{~b}$, respectively. In addition, the crystal band axis of TiFe phase with BCC structure is [001], and the three corresponding crystal planes are (110), (110), and (020), respectively. The diffraction spots in Figure $4 \mathrm{~d}$ are derived from the electron diffraction in the " $\mathrm{B}$ " region marked in Figure $4 \mathrm{c}$ to better display the diffraction of gray striped $\alpha$-Ti grain, and the crystal band axis and the corresponding diffraction plane are also the same as the diffraction spots of the corresponding $\alpha$-Ti phase in Figure $4 \mathrm{~b}$. In Figure $4 \mathrm{f}$, the diffraction spots of BCC $\beta$-Ti phase are electron diffraction in Figure 4e. The crystal band axis of the $\beta$-Ti phase is [113], and the three corresponding diffraction planes of (110), $(\overline{2} 1 \overline{1})$, and $(\overline{1} 2 \overline{1})$ is also labeled in Figure $4 \mathrm{f}$, respectively.
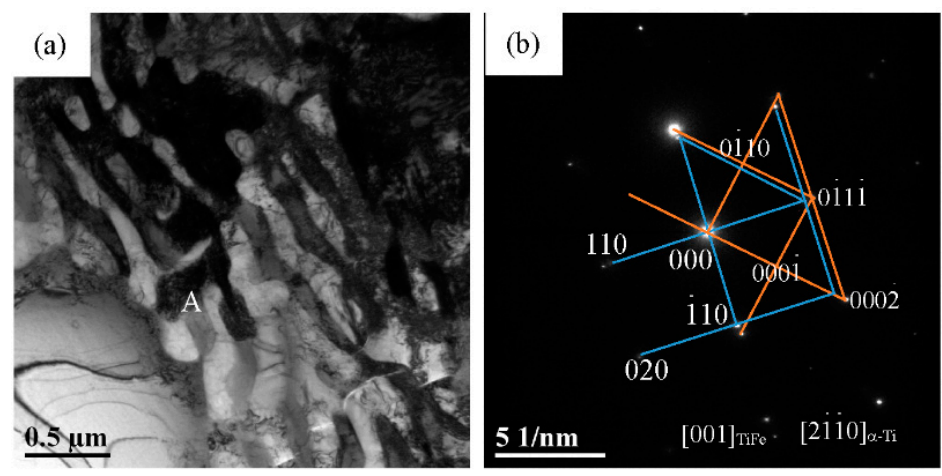

Figure 4. Cont. 

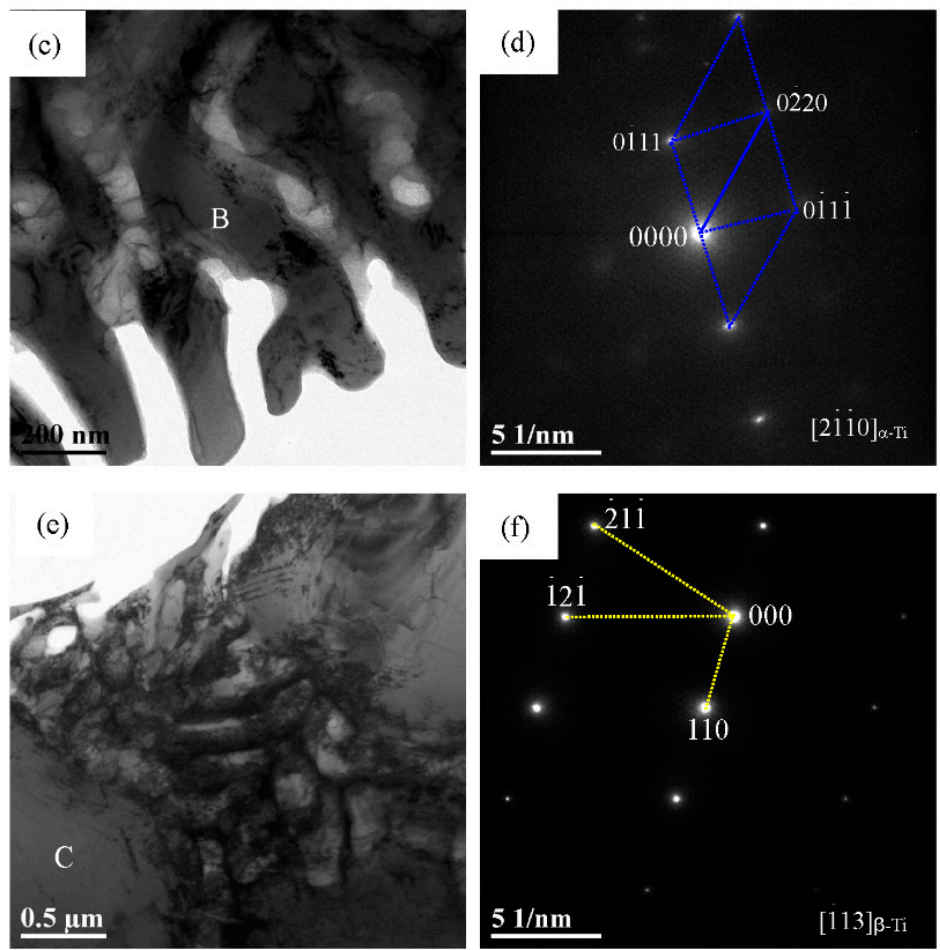

Figure 4. Transmission electron microscope (TEM) bright field images (a,c,e) of $\mathrm{Ti}_{75} \mathrm{Fe}_{19} \mathrm{Sn}_{5} \mathrm{Mo}_{1}$ alloys . $(\mathbf{b}, \mathbf{d}, \mathbf{f})$ Electron diffraction patterns taken respectively from the areas marked " $A$ ", " $B$ ", and " $C$ " in $(\mathbf{a}, \mathbf{c}, \mathbf{e})$.

\subsection{Mechanical Properties of Ti-Fe-Sn-Mo Alloys}

Figure 5 shows the stress-strain curves of the Ti-Fe-Sn-Mo alloys. Table 1 lists the mechanical data calculated by Figure $5 \mathrm{a}$. The results show that the linear elastic limit $\left(\sigma_{\mathrm{e}}\right)$ and the $0.2 \%$ offset yield strength $\left(\sigma_{0.2}\right)$ of the $\mathrm{Ti}_{75} \mathrm{Fe}_{19} \mathrm{Sn}_{5} \mathrm{Mo}_{1}$ alloy are $1502 \mathrm{MPa}$ and $1734 \mathrm{MPa}$, respectively, which are larger than those of the $\mathrm{Ti}_{75} \mathrm{Fe}_{17} \mathrm{Sn}_{5} \mathrm{Mo}_{3}$ and $\mathrm{Ti}_{75} \mathrm{Fe}_{15} \mathrm{Sn}_{5} \mathrm{Mo}_{5}$ alloys in Table 1. The plastic deformation $\left(\varepsilon_{\mathrm{p}}\right)$ of the $\mathrm{Ti}_{75} \mathrm{Fe}_{19} \mathrm{Sn}_{5} \mathrm{Mo}_{1}$ alloy is $16.1 \%$, which is larger than those of $\mathrm{Ti}_{75} \mathrm{Fe}_{17} \mathrm{Sn}_{5} \mathrm{Mo}_{3}$ and $\mathrm{Ti}_{75} \mathrm{Fe}_{15} \mathrm{Sn}_{5} \mathrm{Mo}_{5}$ alloys, and it is also larger than that of the $\mathrm{Ti}_{75} \mathrm{Fe}_{20} \mathrm{Sn}_{5}$ alloy (10.4\%) [11]. In addition, the $\mathrm{Ti}_{75} \mathrm{Fe}_{19} \mathrm{Sn}_{5} \mathrm{Mo}_{1}$ alloy $(2590 \mathrm{MPa})$ has the maximum compressive strength $\left(\sigma_{\mathrm{b}}\right)$ in the present Ti-Fe-Sn-Mo alloys, which are also higher than that of $\mathrm{Ti}_{75} \mathrm{Fe}_{20} \mathrm{Sn}_{5}$ alloy (2332 MPa) [11]. In fact, the yield strength, plastic deformation, and maximum compressive strength of $\mathrm{Ti}_{75} \mathrm{Fe}_{19} \mathrm{Sn}_{5} \mathrm{Mo}_{1}$ alloy are the largest in the Ti-Fe-Sn-Mo and reported Ti-Fe-Sn alloys [11]. Accordingly, the addition of minor Mo element significantly improves the strength and plastic deformation of $\mathrm{Ti}_{75} \mathrm{Fe}_{20} \mathrm{Sn}_{5}$ alloy.

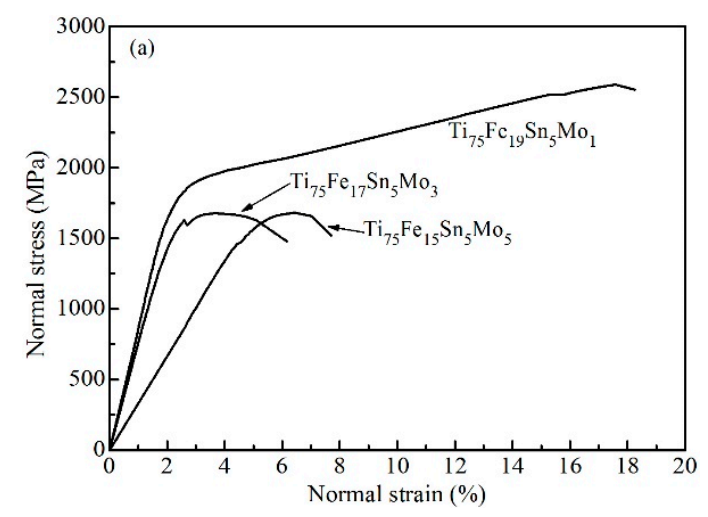

(a)

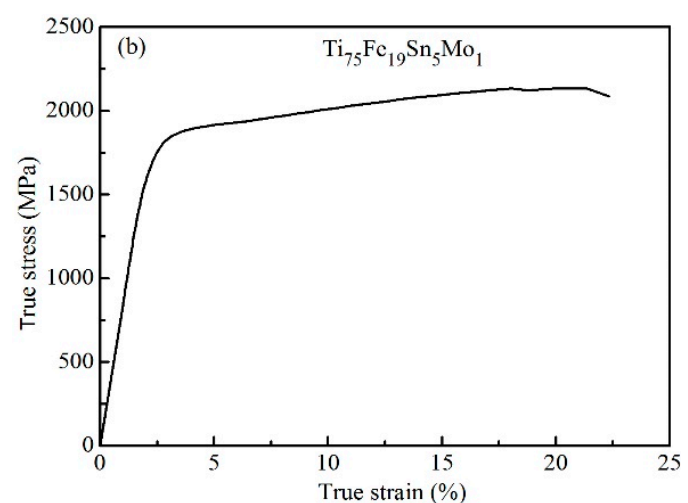

(b)

Figure 5. The (a) normal and (b) true stress-strain curves of the Ti-Fe-Sn-Mo alloys. 
As the density of Mo element $\left(10.22 \mathrm{~g} \cdot \mathrm{cm}^{-3}\right)$ is larger than that of Fe element $\left(7.86 \mathrm{~g} \cdot \mathrm{cm}^{-3}\right)$, when the Mo element partially replaces the Fe element, the densities of Ti-Fe-Sn-Mo alloys increase with the increase of Mo content. The densities of Ti-Fe-Sn-Mo alloys are from the $5.475 \mathrm{~g} \cdot \mathrm{cm}^{-3}$ of Ti ${ }_{75} \mathrm{Fe}_{19} \mathrm{Sn}_{5} \mathrm{Mo}_{1}$ alloy to $5.624 \mathrm{~g} \cdot \mathrm{cm}^{-3}$ of $\mathrm{Ti}_{75} \mathrm{Fe}_{15} \mathrm{Sn}_{5} \mathrm{Mo}_{5}$ alloy. As an engineering material, the specific strength of Ti-rich Ti alloy has important practical significance in engineering applications. The specific yield strength $\left(\sigma_{0.2} / \rho\right)$ and specific compressive strength $\left(\sigma_{\mathrm{b}} / \rho\right)$ of the $\mathrm{Ti}_{75} \mathrm{Fe}_{19} \mathrm{Sn}_{5} \mathrm{Mo}_{1}$ alloy are $316.7 \mathrm{~Pa} \cdot \mathrm{m}^{3} \cdot \mathrm{g}^{-1}$ and 473.1 Pa $\cdot \mathrm{m}^{3} \cdot \mathrm{g}^{-1}$, respectively, which are larger than those of the $\mathrm{Ti}_{75} \mathrm{Fe}_{20} \mathrm{Sn}_{5}$ alloy $\left(308.53 \mathrm{~Pa} \cdot \mathrm{m}^{3} \cdot \mathrm{g}^{-1}\right.$ and $423.23 \mathrm{~Pa} \cdot \mathrm{m}^{3} \cdot \mathrm{g}^{-1}$, respectively) [11], and they are also larger than those of the $\mathrm{Ti}_{75} \mathrm{Fe}_{17} \mathrm{Sn}_{5} \mathrm{Mo}_{3}$ and $\mathrm{Ti}_{75} \mathrm{Fe}_{15} \mathrm{Sn}_{5} \mathrm{Mo}_{5}$ alloys (see Table 3). In addition, the Vickers hardness (HV) of $\mathrm{Ti}_{75} \mathrm{Fe}_{19} \mathrm{Sn}_{5} \mathrm{Mo}_{1}$ and $\mathrm{Ti}_{75} \mathrm{Fe}_{17} \mathrm{Sn}_{5} \mathrm{Mo}_{3}$ alloys are $590 \mathrm{HV}$ and $571 \mathrm{HV}$, respectively, which are larger than those of $\mathrm{Ti}_{75} \mathrm{Fe}_{20} \mathrm{Sn}_{5}$ (558 HV) [11] and $\mathrm{Ti}_{75} \mathrm{Fe}_{15} \mathrm{Sn}_{5} \mathrm{Mo}_{5}$ alloys (534 HV) in Table 1. Accordingly, the addition of an appropriate Mo element can improve the specific strength and Vickers hardness of $\mathrm{Ti}_{75} \mathrm{Fe}_{20} \mathrm{Sn}_{5}$ alloy.

Table 3. Density $(\rho)$ and mechanical properties of Ti-Fe-Sn-Mo alloys. Such as specified yield strength $\left(\sigma_{0.2} / \rho\right)$, specific maximum strength $\left(\sigma_{\mathrm{b}} / \rho\right)$, harden $(H)$, reduced elastic modulus $\left(E_{\mathrm{r}}\right), H / E_{\mathrm{r}}, H^{3} / E_{\mathrm{r}}{ }^{2}$, $U_{\mathrm{e}}, U_{\mathrm{p}}, U_{\mathrm{e}} / U_{\mathrm{t}}$, and $U_{\mathrm{p}} / U_{\mathrm{t}}$ (where $U_{\mathrm{p}}, U_{\mathrm{e}}$, and $U_{\mathrm{t}}$ denote the plastic, elastic, and total indentation energies, respectively).

\begin{tabular}{|c|c|c|c|c|c|c|c|c|c|c|c|}
\hline \multirow{2}{*}{ Alloys } & $\rho$ & $\sigma_{0.2}$ & $\sigma_{\mathbf{b}}$ & $E_{\mathrm{r}}$ & $H$ & \multirow{2}{*}{$H / E_{\mathrm{r}}$} & $H^{3} / E_{\mathrm{r}}^{2}$ & $U_{\mathrm{e}} \times 10^{-11}$ & $U_{\mathrm{p}} \times 10^{-11}$ & $U_{\mathrm{e}} / U_{\mathrm{t}}$ & $U_{\mathrm{p}} / U_{\mathrm{t}}$ \\
\hline & $\left(\mathrm{g} \mathrm{cm}^{-3}\right)$ & $\left(\mathrm{Pa} \mathrm{m}^{3} \mathrm{~g}^{-1}\right)$ & $\left(\mathrm{Pa} \mathrm{m}^{3} \mathrm{~g}^{-1}\right)$ & (GPa) & (GPa) & & (GPa) & $\left(\mathrm{J} \mathrm{m}^{-3}\right)$ & $\left(\mathrm{J} \mathrm{m}^{-3}\right)$ & $(\%)$ & (\%) \\
\hline $\mathrm{Ti}_{75} \mathrm{Fe}_{19} \mathrm{Sn}_{5} \mathrm{Mo}_{1}$ & 5.475 & 316.7 & 473.1 & 110.8 & 6.84 & 0.062 & 0.026 & 26.71 & 36.61 & 42.2 & 57.8 \\
\hline $\mathrm{Ti}_{75} \mathrm{Fe}_{17} \mathrm{Sn}_{5} \mathrm{Mo}_{3}$ & 5.496 & 281.7 & 305.7 & 51.1 & 6.24 & 0.122 & 0.093 & 52.75 & 35.92 & 59.5 & 40.5 \\
\hline $\mathrm{Ti}_{75} \mathrm{Fe}_{15} \mathrm{Sn}_{5} \mathrm{Mo}_{5}$ & 5.624 & 266 & 299.3 & 42.1 & 6.4 & 0.152 & 0.148 & 64.81 & 32.24 & 67.5 & 32.5 \\
\hline
\end{tabular}

In quasi-static compression test, the elastic modulus $(E)$ of alloys can be calculated according to the slope of stress-strain curve at the linear elastic stage. Table 1 lists the calculated $E$ values of the three alloys. The $E$ value of $\mathrm{Ti}_{75} \mathrm{Fe}_{19} \mathrm{Sn}_{5} \mathrm{Mo}_{1}$ alloy is $85.4 \mathrm{GPa}$, higher than those of $\mathrm{Ti}_{75} \mathrm{Fe}_{17} \mathrm{Sn}_{5} \mathrm{Mo}_{3}$ $(74.0 \mathrm{GPa})$ and $\mathrm{Ti}_{75} \mathrm{Fe}_{15} \mathrm{Sn}_{5} \mathrm{Mo}_{5}(33.4 \mathrm{GPa})$ alloys, which indicates that the $E$ values decreases with the increase of Mo content. In fact, the elastic modulus of the $\mathrm{Ti}_{75} \mathrm{Fe}_{15} \mathrm{Sn}_{5} \mathrm{Mo}_{5}$ alloy is very close to that of human bone (10-30 GPa) $[8,9,30]$, indicating that the alloy is a good biomedical material. In fact, the $E$ values for the $\mathrm{Ti}_{75} \mathrm{Fe}_{19} \mathrm{Sn}_{5} \mathrm{Mo}_{1}$ and $\mathrm{Ti}_{75} \mathrm{Fe}_{17} \mathrm{Sn}_{5} \mathrm{Mo}_{3}$ alloys are larger than that of the $\mathrm{Ti}_{75} \mathrm{Fe}_{20} \mathrm{Sn}_{5}$ alloy (35.5 GPa) [11]; the $E$ value of $\mathrm{Ti}_{75} \mathrm{Fe}_{15} \mathrm{Sn}_{5} \mathrm{Mo}_{5}$ alloy is close to that of the $\mathrm{Ti}_{75} \mathrm{Fe}_{20} \mathrm{Sn}_{5}$ alloy.

In Figure 5, the $\mathrm{Ti}_{75} \mathrm{Fe}_{19} \mathrm{Sn}_{5} \mathrm{Mo}_{1}$ alloy exhibits work hardening during plastic deformation. The work-hardening index $(n)$ can reflect the resistance of plastic deformation, and, the larger the resistance of plastic deformation is, the larger the $n$ value is. The true stress-strain curve of $\mathrm{Ti}_{75} \mathrm{Fe}_{19} \mathrm{Sn}_{5} \mathrm{Mo}_{1}$ alloy is shown in Figure 5 to calculate the $n$ value. According to the true stress, $\sigma=k \varepsilon^{n}$, where, $k$ is the strength coefficient and $\varepsilon$ is the true strain. The formula of $\ln \sigma=\ln k+n \ln \varepsilon$ can be written to facilitate that calculation of the $n$ value. Figure 6 shows a graph of the relation between $\ln \sigma$ and $\ln \varepsilon$ of the $\mathrm{Ti}_{75} \mathrm{Fe}_{19} \mathrm{Sn}_{5} \mathrm{Mo}_{1}$ alloy. The $n_{1}$ value of elastic-plastic stage is 0.30 and the $n_{2}$ value is equal to 0.07 in the stage of plastic deformation. In fact, the work-hardening ability of materials in the stage of plastic deformation is more meaning than that in elastic-plastic stage. The $n_{2}$ value of the $\mathrm{Ti}_{75} \mathrm{Fe}_{19} \mathrm{Sn}_{5} \mathrm{Mo}_{1}$ alloy is less than those of the $\mathrm{Zr}_{52} \mathrm{Co}_{48}(0.15)$ and $\mathrm{Zr}_{54} \mathrm{Co}_{46}$ (0.09) alloys with the high ductility [31], which indicates that the $\mathrm{Ti}_{75} \mathrm{Fe}_{19} \mathrm{Sn}_{5} \mathrm{Mo}_{1}$ alloy has a small resistance of plastic deformation as compared to the high-ductility $\mathrm{Zr}$-Co alloys [31]. However, the $n_{2}$ value of the $\mathrm{Ti}_{75} \mathrm{Fe}_{19} \mathrm{Sn}_{5} \mathrm{Mo}_{1}$ alloy is larger than that of the $\mathrm{Ti}_{75} \mathrm{Fe}_{20} \mathrm{Sn}_{5}$ alloy (0.012), indicating that a small amount of Mo addition increases the plastic deformation resistance of the $\mathrm{Ti}_{75} \mathrm{Fe}_{20} \mathrm{Sn}_{5}$ alloy. In addition, For the $\mathrm{Ti}_{75} \mathrm{Fe}_{17} \mathrm{Sn}_{5} \mathrm{Mo}_{3}$ and $\mathrm{Ti}_{75} \mathrm{Fe}_{15} \mathrm{Sn}_{5} \mathrm{Mo}_{5}$ alloys, no work-hardening ability is present in the stage of plastic deformation. Accordingly, a proper amount of Mo content not only improves the strength and the plastic deformation, but also improves the work-hardening ability for the $\mathrm{Ti}_{75} \mathrm{Fe}_{20} \mathrm{Sn}_{5}$ alloy. 


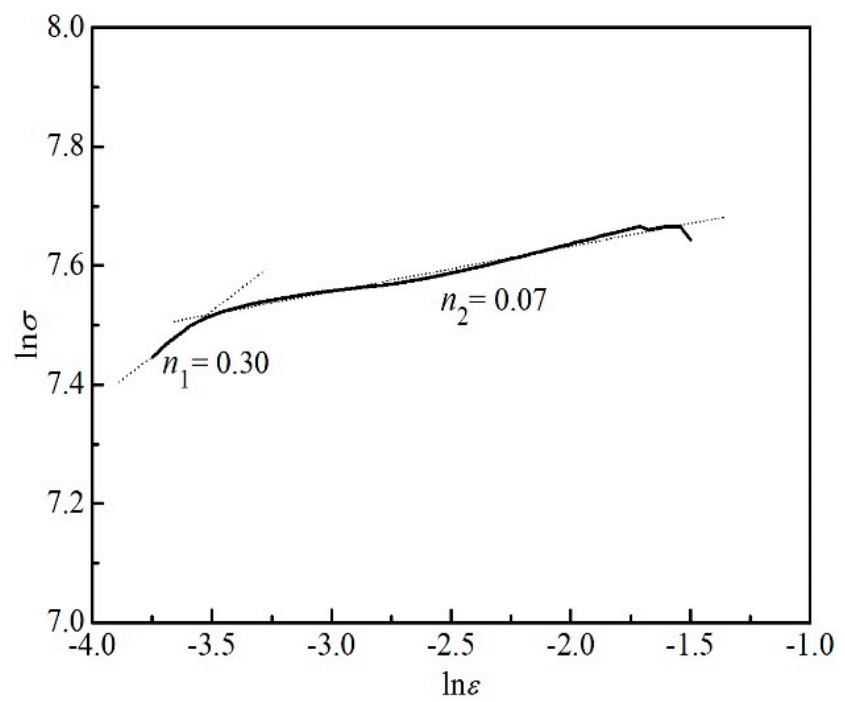

Figure 6. Relationship of $\ln \sigma$ and $\ln \varepsilon$ for the $\mathrm{Ti}_{75} \mathrm{Fe}_{19} \mathrm{Sn}_{5} \mathrm{Mo}_{1}$ alloy.

\subsection{Elastic Energy and Toughness of Ti-Fe-Sn-Mo Alloys}

The Ti alloy can be used not only as biomedical alloy, but also as engineering material. As a biomedical alloy, besides its low elastic modulus, it is necessary to calculate the elastic energy $\left(W_{\mathrm{e}}\right)$ of the alloy, and the larger the elastic energy is, the higher the safety is in the application of biomedical materials. Similarly, as engineering materials, the larger the static compression toughness is, the higher the safety of the material is in engineering application. In Figure 5, as the elastic strain of $\mathrm{Ti}_{75} \mathrm{Fe}_{15} \mathrm{Sn}_{5} \mathrm{Mo}_{5}$ alloy exceeds $4 \%$, the calculation method of elastic energy for the selected $\mathrm{Ti}_{75} \mathrm{Fe}_{15} \mathrm{Sn}_{5} \mathrm{Mo}_{5}$ alloy is shown in Figure 7. Table 1 lists the calculated $W_{\mathrm{e}}$ values of the three alloys. The $W_{\mathrm{e}}$ value of the $\mathrm{Ti}_{75} \mathrm{Fe}_{19} \mathrm{Sn}_{5} \mathrm{Mo}_{1}$ alloy is $13.36 \times 10^{6} \mathrm{~J} \cdot \mathrm{m}^{-3}$, which is larger than that of the $\mathrm{Ti}_{75} \mathrm{Fe}_{17} \mathrm{Sn}_{5} \mathrm{Mo}_{3}$ alloy $\left(10.16 \times 10^{6} \mathrm{~J} \cdot \mathrm{m}^{-3}\right)$, but less than that of the $\mathrm{Ti}_{75} \mathrm{Fe}_{15} \mathrm{Sn}_{5} \mathrm{Mo}_{5}$ alloy $\left(30.30 \times 10^{6} \mathrm{~J} \cdot \mathrm{m}^{-3}\right)$. Although the $W_{\mathrm{e}}$ values of the Ti-Fe-Sn-Mo alloys are less than that of $\mathrm{Ti}_{75} \mathrm{Fe}_{20} \mathrm{Sn}_{5}$ alloy $\left(67.7 \times 10^{-6} \mathrm{~J} \cdot \mathrm{m}^{-3}\right)$ [11], they are larger than those of Ti-11Nb-9Fe $\left(7.1 \times 10^{6} \mathrm{~J} \cdot \mathrm{m}^{-3}\right)$ and Ti-6Al-4V $\left(2.8 \times 10^{6} \mathrm{~J} \cdot \mathrm{m}^{-3}\right)$ biomedical alloys [30,32]. Therefore, the present Ti-Fe-Sn-Mo alloys can be used as a new biomedical alloys.

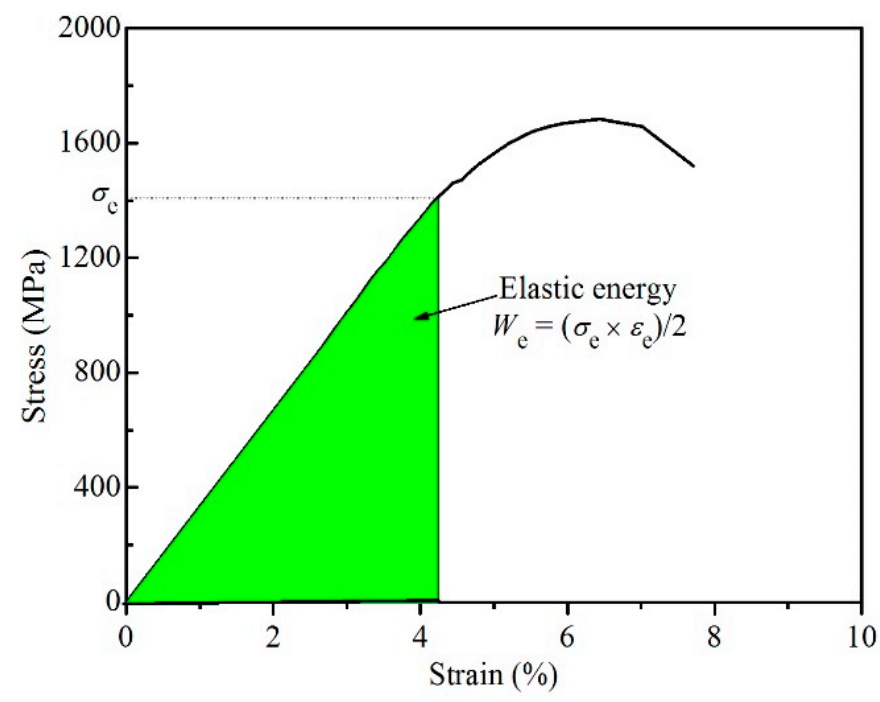

Figure 7. The elastic energy $\left(W_{\mathrm{e}}\right)$ of the $\mathrm{Ti}_{75} \mathrm{Fe}_{15} \mathrm{Sn}_{5} \mathrm{Mo}_{5}$ alloy.

Figure 8 is a method for calculating the toughness $\left(A_{\mathrm{t}}\right)$ of $\mathrm{Ti}_{75} \mathrm{Fe}_{19} \mathrm{Sn}_{5} \mathrm{Mo}_{1}$ alloy at room temperature compression. Table 1 lists the calculated $A_{\mathrm{t}}$ values As the high strength and plastic deformation of 
$\mathrm{Ti}_{75} \mathrm{Fe}_{19} \mathrm{Sn}_{5} \mathrm{Mo}_{1}$ alloy, the toughness value of $\mathrm{Ti}_{75} \mathrm{Fe}_{19} \mathrm{Sn}_{5} \mathrm{Mo}_{1}$ alloy $\left(383.14 \times 10^{6} \mathrm{~J} \mathrm{~m}^{-3}\right)$ is much larger than those of the $\mathrm{Ti}_{75} \mathrm{Fe}_{17} \mathrm{Sn}_{5} \mathrm{Mo}_{3}\left(82.14 \times 10^{6} \mathrm{~J} \mathrm{~m}^{-3}\right)$ and $\mathrm{Ti}_{75} \mathrm{Fe}_{15} \mathrm{Sn}_{5} \mathrm{Mo}_{5}\left(85.70 \times 10^{6} \mathrm{~J} \mathrm{~m}^{-3}\right)$ alloys. In addition, the $A_{\mathrm{t}}$ value of $\mathrm{Ti}_{75} \mathrm{Fe}_{19} \mathrm{Sn}_{5} \mathrm{Mo}_{1}$ alloy is larger than that of $\mathrm{Ti}_{75} \mathrm{Fe}_{20} \mathrm{Sn}_{5}$ alloy $\left(258.66 \times 10^{6} \mathrm{~J} \mathrm{~m}^{-3}\right)$ [11]. Therefore, the appropriate addition of Mo element can improve the $A_{\mathrm{t}}$ value of $\mathrm{Ti}_{75} \mathrm{Fe}_{20} \mathrm{Sn}_{5}$ alloy and thus improve the safety in the application of engineering materials.

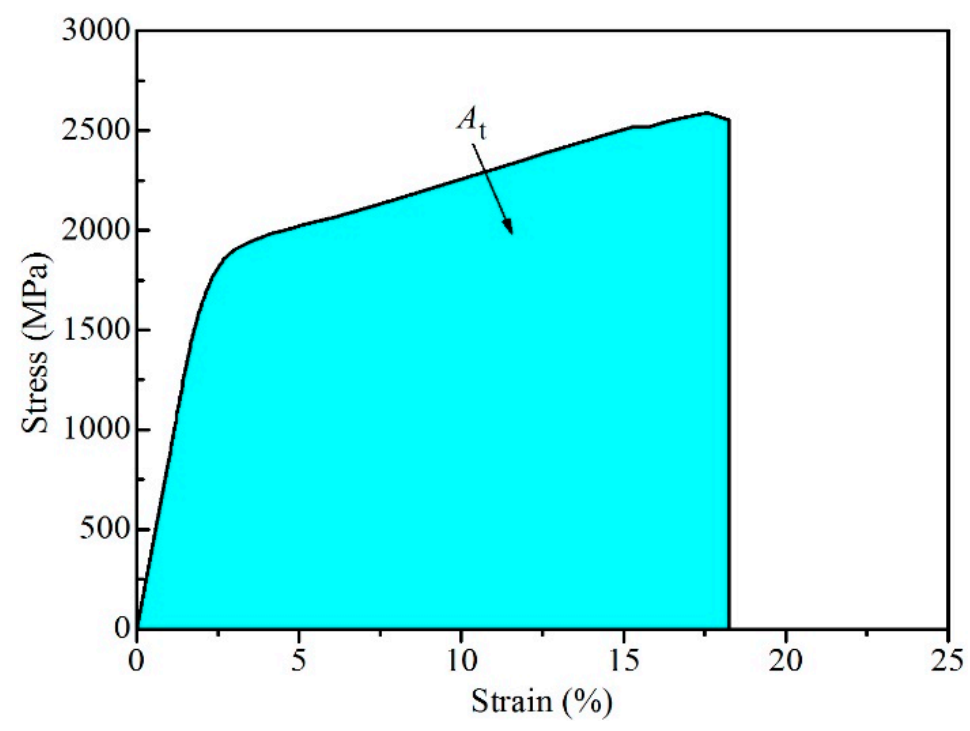

Figure 8. The toughness $\left(A_{\mathrm{t}}\right)$ of the $\mathrm{Ti}_{75} \mathrm{Fe}_{19} \mathrm{Sn}_{5} \mathrm{Mo}_{1}$ alloy.

\subsection{Fracture Morphology of Ti-Fe-Sn-Mo Alloys}

Figure 9 shows the fracture morphology of Ti-Fe-Sn-Mo samples compressed at room temperature. A large area of ductile fracture is observed in Figure $9 \mathrm{a}$ for the fracture morphology of the $\mathrm{Ti}_{75} \mathrm{Fe}_{19} \mathrm{Sn}_{5} \mathrm{Mo}_{1}$ alloy. The formation of ductile region can absorb a large amount of plastic deformation work, which results in large plastic deformation in the process of compression. This is consistent with the large plastic deformation of the $\mathrm{Ti}_{75} \mathrm{Fe}_{19} \mathrm{Sn}_{5} \mathrm{Mo}_{1}$ alloy. In addition, cleavage fracture is also observed in Figure 9a, which is a macroscopic brittle fracture, and cleavage fracture generally occurs in body-centered cubic and closed packing hexagonal metal materials. The $\beta$-Ti and TiFe phases are body-centered cubic and the $\alpha$-Ti phase is closed packing hexagonal, so cleavage fracture can be observed in the compressed fracture morphology, as shown in Figure 9c,e. The larger the area of cleavage fracture is, the less plastic work will be absorbed in plastic deformation, and the smaller the plastic deformation will be. In Figure 9c,e, the region of cleavage fracture is obviously larger than that of thee cleavage fracture in Figure $9 \mathrm{a}$, indicating that the plastic works absorbed for the $\mathrm{Ti}_{75} \mathrm{Fe}_{17} \mathrm{Sn}_{5} \mathrm{Mo}_{3}$ and $\mathrm{Ti}_{75} \mathrm{Fe}_{15} \mathrm{Sn}_{5} \mathrm{Mo}_{5}$ alloys during compression are smaller than those for the $\mathrm{Ti}_{75} \mathrm{Fe}_{19} \mathrm{Sn}_{5} \mathrm{Mo}_{1}$ alloy. It results in the plastic deformation for the $\mathrm{Ti}_{75} \mathrm{Fe}_{17} \mathrm{Sn}_{5} \mathrm{Mo}_{3}$ and $\mathrm{Ti}_{75} \mathrm{Fe}_{15} \mathrm{Sn}_{5} \mathrm{Mo}_{5}$ alloys being smaller than while that for the $\mathrm{Ti}_{75} \mathrm{Fe}_{19} \mathrm{Sn}_{5} \mathrm{Mo}_{1}$ alloy. The results are consistent with the mechanical experimental data observed Table 1. In Figure 9b, a small amount of the intergranular fracture-type dimples are distributed; however, the intergranular fracture-type dimples are not observed in Figure 9d,f. The grain boundary can be easily damaged when the sample is subjected to compressive stress, as a small amount of TiFe phases precipitate along the grain boundary. The movement of dislocation in the grain boundary is affected by the grain boundary, which results in the stress concentration caused at the grain boundary. When the concentration stress reaches the grain boundary strength, the crack at the grain boundary leads to the formation of dimples of intergranular fracture. In addition, a large number of cleavage steps are observed in Figure $9 \mathrm{~d}$,f, which indicates that the fracture mechanism of $\mathrm{Ti}_{75} \mathrm{Fe}_{17} \mathrm{Sn}_{5} \mathrm{Mo}_{3}$ and $\mathrm{Ti}_{75} \mathrm{Fe}_{15} \mathrm{Sn}_{5} \mathrm{Mo}_{5}$ alloys is macroscopic brittle fracture; the cleavage steps are relatively few in Figure $9 \mathrm{~b}$, indicating that the fracture mechanism of $\mathrm{Ti}_{75} \mathrm{Fe}_{19} \mathrm{Sn}_{5} \mathrm{Mo}_{1}$ alloy is macroscopically plastic fracture. 

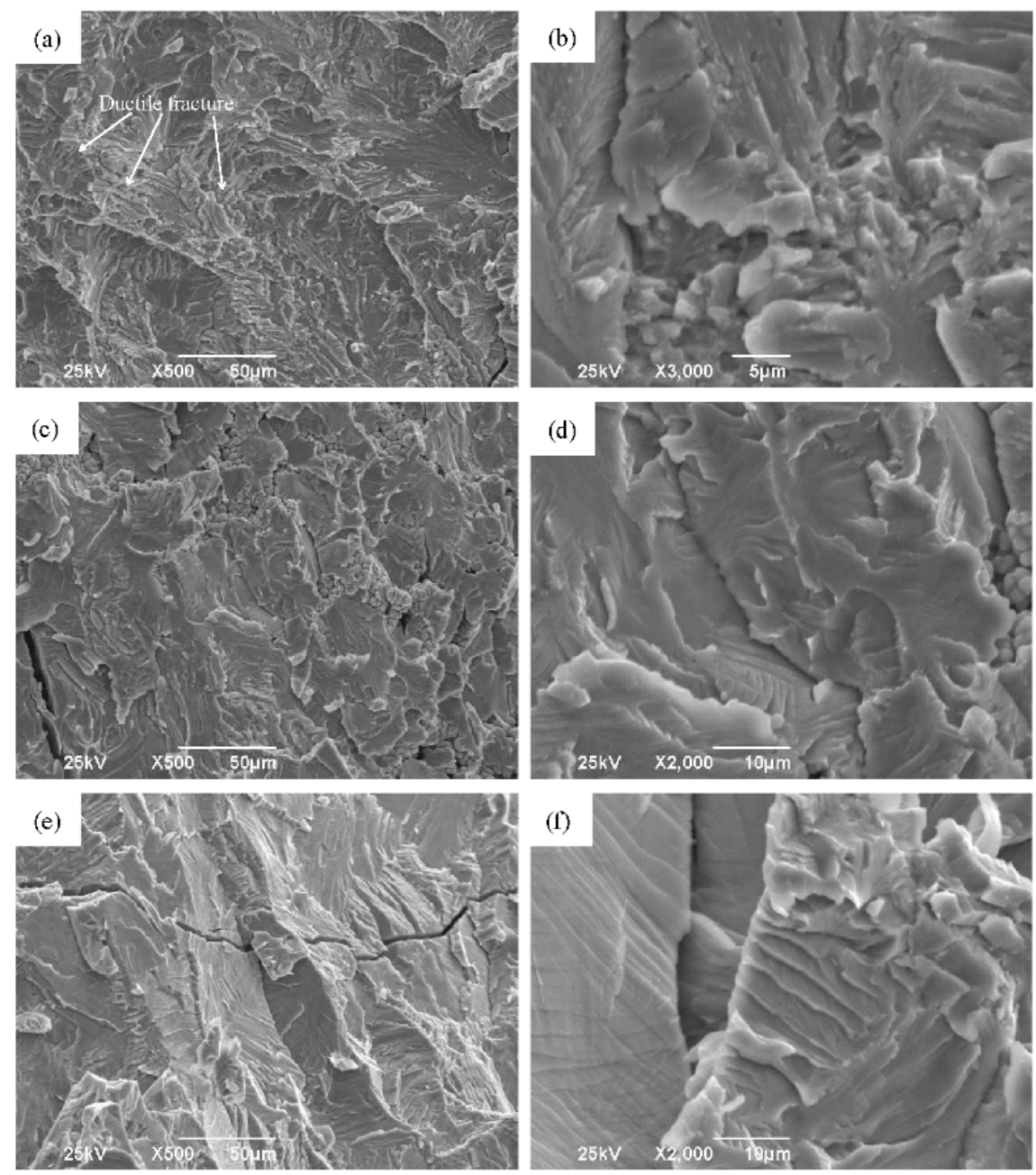

Figure 9. Fracture morphology of as-cast Ti-Fe-Sn-Mo alloys.

(a,b) $\mathrm{Ti}_{75} \mathrm{Fe}_{19} \mathrm{Sn}_{5} \mathrm{Mo}_{1}, \quad(\mathbf{c}, \mathbf{d})$ $\mathrm{Ti}_{75} \mathrm{Fe}_{17} \mathrm{Sn}_{5} \mathrm{Mo}_{3},(\mathbf{e}, \mathbf{f}) \mathrm{Ti}_{75} \mathrm{Fe}_{15} \mathrm{Sn}_{5} \mathrm{Mo}_{5}$.

\subsection{Nanoindentation of Ti-Fe-Sn-Mo Alloys}

The elastic modulus that is measured by the compression instrument might differ greatly from the real value due to the elastic deformation of the instrument in the quasi-compression process. To get closer to the true elastic modulus of materials, the reduced elastic modulus $\left(E_{\mathrm{r}}\right)$ of three Ti-Fe-Sn-Mo alloys were measured by the nanoindentation technique. Figure 10 shows the representative load $(P)$-displacement $(h)$ nanoindentation curves for the Ti-Fe-Sn-Mo alloys. The $E_{\mathrm{r}}$ and hardness $(H)$ values that were measured for the three alloys are listed in Table 3. The $E_{\mathrm{r}}$ values of the $\mathrm{Ti}_{75} \mathrm{Fe}_{19} \mathrm{Sn}_{5} \mathrm{Mo}_{1}$, $\mathrm{Ti}_{75} \mathrm{Fe}_{17} \mathrm{Sn}_{5} \mathrm{Mo}_{3}$, and $\mathrm{Ti}_{75} \mathrm{Fe}_{15} \mathrm{Sn}_{5} \mathrm{Mo}_{5}$ alloys are $110.8 \mathrm{GPa}$, $51.1 \mathrm{GPa}$, and $42.1 \mathrm{GPa}$, respectively. The $E_{\mathrm{r}}$ values of the $\mathrm{Ti}_{75} \mathrm{Fe}_{19} \mathrm{Sn}_{5} \mathrm{Mo}_{1}$ and $\mathrm{Ti}_{75} \mathrm{Fe}_{15} \mathrm{Sn}_{5} \mathrm{Mo}_{5}$ alloys are larger than the $E$ values of two alloys in the quasi-static compression test, but the $E_{\mathrm{r}}$ value of the $\mathrm{Ti}_{75} \mathrm{Fe}_{17} \mathrm{Sn}_{5} \mathrm{Mo}_{3}$ alloy is obviously lower than the $E$ value in the quasi-static compression test. Accordingly, based on the elastic modulus that was measured by the two methods, the $\mathrm{Ti}_{75} \mathrm{Fe}_{19} \mathrm{Sn}_{5} \mathrm{Mo}_{1}$ alloy with a high specific strength has high elastic modulus, which indicates that the alloy is a new type of engineering material with excellent mechanical properties. The elastic modulus of $\mathrm{Ti}_{75} \mathrm{Fe}_{15} \mathrm{Sn}_{5} \mathrm{Mo}_{5}$ alloy is very close to the elastic modulus of human bone, indicating that the alloy can be used as a good biomedical alloy. The hardness value of $\mathrm{Ti}_{75} \mathrm{Fe}_{19} \mathrm{Sn}_{5} \mathrm{Mo}_{1}$ alloy is $6.84 \mathrm{GPa}$, higher than that of the $\mathrm{Ti}_{75} \mathrm{Fe}_{17} \mathrm{Sn}_{5} \mathrm{Mo}_{3}$ (6.24 GPa) and $\mathrm{Ti}_{75} \mathrm{Fe}_{15} \mathrm{Sn}_{5} \mathrm{Mo}_{5}(6.40 \mathrm{GPa})$ alloys, respectively. In fact, the $H$ values of the three alloys are larger than that of the $\mathrm{Ti}_{75} \mathrm{Fe}_{20} \mathrm{Sn}_{5}$ alloy (5.00 GPa), which indicates that the addition of Mo element improves the hardness of the $\mathrm{Ti}_{75} \mathrm{Fe}_{20} \mathrm{Sn}_{5}$ alloys. 


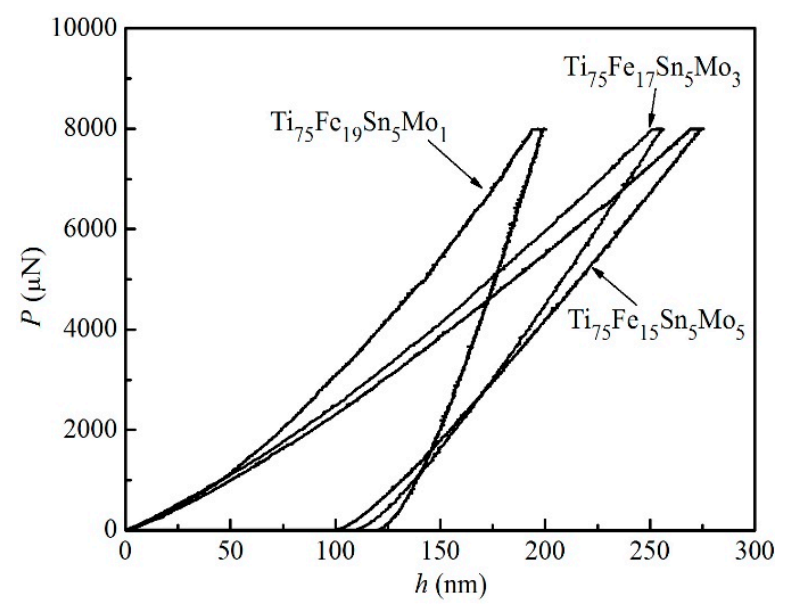

Figure 10. Representative load/unload $(P)$-displacement $(h)$ nanoindentation curves for the Ti-Fe-Sn-Mo alloys.

Wear behavior of engineering materials and hard tissue implant materials occurs during their application. The longer the service life of materials with good wear resistance is in use. The wear resistance of materials is not only related to the hardness, strength, and plasticity of materials, but also to the structure and environment of materials. When these wear-resistant experiments are completed, a lot of manpower, material resources, and experimental costs are needed. As a new material, some researchers have found that some parameters can qualitatively characterize the wear resistance of materials, thus saving manpower, material resources and experimental costs for the selection of wear resistant materials. The parameter $H / E_{\mathrm{r}}$ can characterize the wear resistance of materials based on the measured $E_{\mathrm{r}}$ and $H$ values [33]. The greater the $H / E_{\mathrm{r}}$ value is, the better wear resistance of materials is, and the longer the corresponding service life is [33]. However, the $\mathrm{Ti}_{75} \mathrm{Fe}_{15} \mathrm{Sn}_{5} \mathrm{Mo}_{5}$ alloy has the highest $H / E_{\mathrm{r}}$ value, being 0.152 , which is larger than that of $\mathrm{Ti}_{75} \mathrm{Fe}_{20} \mathrm{Sn}_{5}$ alloy (0.149). In addition, the $H / E_{\mathrm{r}}$ values of $\mathrm{Ti}_{75} \mathrm{Fe}_{19} \mathrm{Sn}_{5} \mathrm{Nb}_{1}$ and $\mathrm{Ti}_{75} \mathrm{Fe}_{17} \mathrm{Sn}_{5} \mathrm{Mo}_{3}$ alloys are 0.062 and 0.122 , respectively, which are smaller than those of $\mathrm{Ti}_{75} \mathrm{Fe}_{15} \mathrm{Sn}_{5} \mathrm{Mo}_{5}$ and $\mathrm{Ti}_{75} \mathrm{Fe}_{20} \mathrm{Sn}_{5}$ alloys. The results show that the wear resistance and service life of the alloy can be improved by adding a suitable Mo element. In fact, the reported parameter $H^{3} / E_{\mathrm{r}}{ }^{2}$ can also characterize the anti-wear ability of materials [34]. The $H^{3} / E_{\mathrm{r}}{ }^{2}$ values increase from $0.026 \mathrm{GPa}$ of $\mathrm{Ti}_{75} \mathrm{Fe}_{19} \mathrm{Sn}_{5} \mathrm{Mo}_{1}$ alloy to $0.148 \mathrm{GPa}$ of $\mathrm{Ti}_{75} \mathrm{Fe}_{15} \mathrm{Sn}_{5} \mathrm{Mo}_{5}$ alloy. In particular, the $H^{3} / E_{\mathrm{r}}^{2}$ value of $\mathrm{Ti}_{75} \mathrm{Fe}_{15} \mathrm{Sn}_{5} \mathrm{Mo}_{5}$ alloy is larger than that of $\mathrm{Ti}_{75} \mathrm{Fe}_{20} \mathrm{Sn}_{5}$ alloy without Mo element, which indicates that the $\mathrm{Ti}_{75} \mathrm{Fe}_{15} \mathrm{Sn}_{5} \mathrm{Mo}_{5}$ alloy has good anti-wear ability and long service life. In fact, the $H / E_{\mathrm{r}}$ and $H^{3} / E_{\mathrm{r}}{ }^{2}$ values of $\mathrm{Ti}_{75} \mathrm{Fe}_{19} \mathrm{Sn}_{5} \mathrm{Mo}_{1}$ alloy with high strength and plasticity are larger than those of CP-Ti and biomedical Ti-Nb-Sn alloys [11,35], which indicates that the $\mathrm{Ti}_{75} \mathrm{Fe}_{19} \mathrm{Sn}_{5} \mathrm{Mo}_{1}$ alloy has good wear resistance and long service life as biomedical materials.

Figure 11 shows the loading-displacement curve of the $\mathrm{Ti}_{75} \mathrm{Fe}_{19} \mathrm{Sn}_{5} \mathrm{Mo}_{1}$ alloy, which is different from the nanoindentation curve in Figure 10. The displacement of the unloading curve in Figure 11 is obtained by using the displacement of the unloading curve subtracts the isobaric displacement to show the relationship between plastic and elastic energy. Based on the method in Figure 11, Table 3 lists the calculated elastic energy $\left(U_{\mathrm{e}}\right)$ and plastic energy $\left(U_{\mathrm{p}}\right)$ of the three alloys. The $U_{\mathrm{e}}$ values increase from $26.71 \times 10^{-11} \mathrm{~J} \cdot \mathrm{m}^{-3}$ of the $\mathrm{Ti}_{75} \mathrm{Fe}_{19} \mathrm{Sn}_{5} \mathrm{Mo}_{1}$ alloy to $64.81 \times 10^{-11} \mathrm{~J} \cdot \mathrm{m}^{-3}$ of the $\mathrm{Ti}_{75} \mathrm{Fe}_{15} \mathrm{Sn}_{5} \mathrm{Mo}_{5}$ alloy; the $U_{\mathrm{p}}$ values decrease from $36.61 \times 10^{-11} \mathrm{~J} \cdot \mathrm{m}^{-3}$ of $\mathrm{Ti}_{75} \mathrm{Fe}_{19} \mathrm{Sn}_{5} \mathrm{Mo}_{1}$ alloy to $32.24 \times 10^{-11} \mathrm{~J} \cdot \mathrm{m}^{-3}$ of the $\mathrm{Ti}_{75} \mathrm{Fe}_{15} \mathrm{Sn}_{5} \mathrm{Mo}_{5}$ alloy. The sum of elastic energy and plastic energy is equal to the work done by nano-indentation displacement during loading, that is, $U_{\mathrm{t}}=U_{\mathrm{e}}+U_{\mathrm{p}}[35,36]$. The elastic recovery parameter $\left(U_{\mathrm{e}} / U_{\mathrm{t}}\right)$ can denote the resistance of materials under impact loading [33], and the plasticity index $\left(U_{\mathrm{p}} / U_{\mathrm{t}}\right)$ indicates the intrinsic plasticity of materials [33]. Table 3 lists the calculated $U_{\mathrm{e}} / U_{\mathrm{t}}$ and $U_{\mathrm{p}} / U_{\mathrm{t}}$ values. The $\mathrm{Ti}_{75} \mathrm{Fe}_{15} \mathrm{Sn}_{5} \mathrm{Mo}_{5}$ alloy has the largest $U_{\mathrm{e}} / U_{\mathrm{t}}$ value $(67.5 \%)$, while the $\mathrm{Ti}_{75} \mathrm{Fe}_{19} \mathrm{Sn}_{5} \mathrm{Mo}_{1}$ alloy has the smallest $U_{\mathrm{e}} / U_{\mathrm{t}}$ value (42.2\%) in Table 3, indicating that the $\mathrm{Ti}_{75} \mathrm{Fe}_{15} \mathrm{Sn}_{5} \mathrm{Mo}_{5}$ alloy has the high resistance of impact loading, while the $\mathrm{Ti}_{75} \mathrm{Fe}_{19} \mathrm{Sn}_{5} \mathrm{Mo}_{1}$ alloy has the weak resistance of impact 
loading in the present Ti-Fe-Sn-Mo alloys. However, the $U_{\mathrm{e}} / U_{\mathrm{t}}$ values of the Ti-Fe-Sn-Mo alloys are far larger than those of the Ti-Co-Zr alloys $(<28.5 \%)$ and CP-Ti alloy $(20.4 \%)[5,33]$, indicating that the three alloys have good impact resistance. The $U_{\mathrm{p}} / U_{\mathrm{t}}$ value of $\mathrm{Ti}_{75} \mathrm{Fe}_{19} \mathrm{Sn}_{5} \mathrm{Mo}_{1}$ alloy $(57.8 \%)$ is larger than those of $\mathrm{Ti}_{75} \mathrm{Fe}_{17} \mathrm{Sn}_{5} \mathrm{Mo}_{3}(40.5 \%)$ and $\mathrm{Ti}_{75} \mathrm{Fe}_{15} \mathrm{Sn}_{5} \mathrm{Mo}_{5}$ (32.5\%) alloys, which indicates that the $\mathrm{Ti}_{75} \mathrm{Fe}_{19} \mathrm{Sn}_{5} \mathrm{Mo}_{1}$ alloy has good intrinsic plasticity.

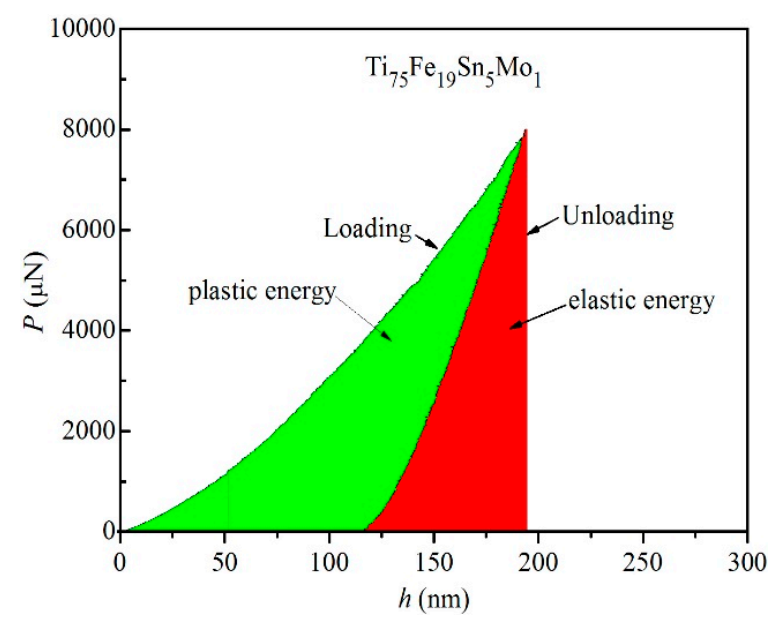

Figure 11. Loading and unloading in a cycle of indentation and corresponding energy fractions for the $\mathrm{Ti}_{75} \mathrm{Fe}_{19} \mathrm{Sn}_{5} \mathrm{Mo}_{1}$ alloy.

\section{Conclusions}

The microstructure and mechanical properties of rapidly solidified $\beta$-type Ti-Fe-Sn-Mo alloys with high specific strength and low elastic modulus were investigated, and the main conclusion are as follows,

(1) The results show that the matrix phase of the $\mathrm{Ti}_{75} \mathrm{Fe}_{19} \mathrm{Sn}_{5} \mathrm{Mo}_{1}$ and $\mathrm{Ti}_{75} \mathrm{Fe}_{15} \mathrm{Sn}_{5} \mathrm{Mo}_{5}$ alloys is the $\alpha$-Ti phase, and the second phases are the $\beta$-Ti and TiFe phases, while the matrix phase of the $\mathrm{Ti}_{75} \mathrm{Fe}_{17} \mathrm{Sn}_{5} \mathrm{Mo}_{5}$ alloy is the $\beta$-Ti phase, and the second phases are the $\alpha$-Ti and TiFe phases. The volume fraction of TiFe phase decreases with the increase of Mo content. The high Fe content results in deposition along the grain boundary of Ti phase.

(2) The $\mathrm{Ti}_{75} \mathrm{Fe}_{19} \mathrm{Sn}_{5} \mathrm{Mo}_{1}$ alloy exhibits the high yield strength (1734 MPa), maximum compressive strength $(2590 \mathrm{MPa})$, large plastic deformation $(16.1 \%)$, high specific yield and compressive strength (316.7 Pa $\cdot \mathrm{m}^{3} \cdot \mathrm{g}^{-1}$ and $\left.473.1 \mathrm{~Pa} \cdot \mathrm{m}^{3} \cdot \mathrm{g}^{-1}\right)$, high Vickers hardness $(590 \mathrm{HV})$, and large toughness value $\left(383.14 \times 106 \mathrm{~J} \cdot \mathrm{m}^{-3}\right)$, which is a superior new engineering material.

(3) The elastic modulus (42.1 GPa) of the $\mathrm{Ti}_{75} \mathrm{Fe}_{15} \mathrm{Sn}_{5} \mathrm{Mo}_{5}$ alloy is very close to the elastic modulus of human bone (10-30 GPa), which indicates that the alloy can be used as a good biomedical alloy. In addition, the large $H / E_{\mathrm{r}}$ and $H^{3} / E_{\mathrm{r}}^{2}$ values of $\mathrm{Ti}_{75} \mathrm{Fe}_{19} \mathrm{Sn}_{5} \mathrm{Mo}_{1}$ alloy indicates the good wear resistance and long service life as biomedical materials; the large $U_{e} / U_{t}$ of three Ti-Fe-Sn-Mo alloys indicate good impact resistance.

Author Contributions: P.L., X.M. and Y.J. conceived and designed the experiments; P.L., X.M., Y.J., F.M. and L.T. performed the experiments, analyzed the data; P.L. wrote original draft preparation; P.L. and Z.H. wrote review and editing.

Funding: This research received no external funding.

Conflicts of Interest: The authors declare no conflict of interest. 


\section{References}

1. Lin, P.; Tang, T.T.; Chi, C.Z.; Zhang, S.Z.; Zhang, C.J. Dynamic globularization behavior of O-Phase lamellae in Ti-22Al-25Nb (at.\%) alloy during deformation at elevated temperatures. Rare Met. Mater. Eng. 2018, 47, 416-422.

2. Li, P.Y. Microstructural and mechanical properties of novel $\beta$-type $\mathrm{Ti}-\mathrm{Nb}-\mathrm{Ni}$ alloys containing a second phase. Int. J. Mater. Res. 2018, 109, 708-715. [CrossRef]

3. Li, P.Y.; Ma, X.D.; Wang, D.; Zhang, H. Microstructural and mechanical properties of $\beta$-type Ti-Nb-Sn biomedical alloys with low elastic modulus. Metals 2019, 9, 712. [CrossRef]

4. Cao, S.Z.; Xia, S.L.; Chen, Y.Y.; Xu, L.J.; Wang, X.P.; Han, J.C.; Jia, Y. Phase transformations of the $\mathrm{L1}_{2}-\mathrm{Ti}_{3} \mathrm{Al}_{1}$ phase in $\gamma$-TiAl alloy. Mater. Des. 2017, 121, 61-68. [CrossRef]

5. Li, P.Y. Microstructure and mechanical properties of novel $\beta$-type Ti-Co-Zr alloys with high specific strength. Mater. Res. Express 2019, 6, 076559. [CrossRef]

6. Long, M.; Rack, H.J. Titanium alloys in total joint replacement-A materials science perspective. Biomaterials 1998, 19, 1621-1639. [CrossRef]

7. Wang, K. The use of titanium for medical applications in the USA. Mater. Sci. Eng. A 1996, 213, $134-137$. [CrossRef]

8. Niinomi, M. Recent metallic materials for biomedical applications. Metall. Mater. Trans. A 2002, 33, 477-486. [CrossRef]

9. Niinomi, M. Recent research and development in titanium alloys for biomedical applications and healthcare goods. Sci. Technol. Adv. Mater. 2003, 4, 445-454. [CrossRef]

10. Hanada, S.; Masahashi, N.; Jung, T.K.; Yamada, N.; Yamako, G.; Itoi, E. Fabrication of a High-Performance hip prosthetic stem using $\beta$ Ti-33.6Nb-4Sn. J. Mech. Behav. Biomed. Mater. 2014, 30, 140-149. [CrossRef]

11. Li, P.Y.; Zhang, H.; Tong, T.; He, Z.R. The rapidly solidified $\beta$-type Ti-Fe-Sn alloys with high specific strength and low elastic modulus. J. Alloys Compds. 2019, 786, 986-994. [CrossRef]

12. Zhao, G.H.; Ketov, S.V.; Jiang, J.; Mao, H.; Borgenstam, A.; Louzguine-Luzgin, D.V. New Beta-Type Ti-Fe-Sn-Nb alloys with superior mechanical strength. Mater. Sci. Eng. A 2017, 705, 348-351. [CrossRef]

13. Haghighi, S.E.; Lu, H.B.; Jian, G.Y.; Cao, G.H.; Habibi, D.; Zhang, L.C. Effect of martensite on the microstructure and mechanical properties of beta-type Ti-Fe-Ta alloys. Mater. Des. 2015, 76, 47-54. [CrossRef]

14. Pettan, G.C.; Afonso, C.R.; Spinelli, J.E. Microstructure development and mechanical properties of rapidly solidified Ti-Fe and Ti-Fe-Bi alloys. Mater. Des. 2015, 86, 221-229. [CrossRef]

15. Das, J.; Kim, K.B.; Baier, F. High-Strength Ti-Base ultrafine eutectic with enhanced ductility. Appl. Phys. Lett. 2005, 87, 161907. [CrossRef]

16. Louzguine, D.V.; Kato, H.; Inoue, A. High strength and ductile binary Ti-Fe composite alloy. J. Alloys Compd. 2004, 384, L1-L3. [CrossRef]

17. Han, J.H.; Park, D.H.; Bang, C.W.; Yi, S.; Lee, W.H.; Kim, K.B. Sn effect on microstructure and mechanical properties of ultrafine eutectic Ti-Fe-Sn alloys. J. Alloys Compd. 2009, 483, 44-46. [CrossRef]

18. Han, J.H.; Kim, K.B.; Yi, S.; Park, J.M.; Sohn, S.W.; Kim, T.E.; Kim, D.H.; Das, J.; Eckert, J. Formation of a bimodal eutectic structure in Ti-Fe-Sn alloys with enhanced plasticity. Appl. Phys. Lett. 2008, 93, 141901. [CrossRef]

19. Cao, G.H.; Schneider, R.; Gerthsen, D.; Chulist, R.; Schaarschuch, R.; Oertel, C.G.; Skrotzki, W. Sn and Nb modified ultrafine bulk alloys with High-Strength and enhanced ductility. Appl. Phys. Lett. 2013, 102, 061908. [CrossRef]

20. Zadorozhnyy, V.Y.; Shchetinin, I.V.; Chirikov, N.V.; Louzguine-Luzgin, D.V. Tensile properties of a dual-axial forged Ti-Fe-Cu alloy containing boron. Mater. Sci. Eng. A 2014, 614, 238-242. [CrossRef]

21. Zadorozhnyy, V.Y.; Inoue, A.; Louzguine, D.V. Ti-Based nanostructured Low-Alloy with high strength and ductility. Mater. Sci. Eng. A 2012, 551, 82-86. [CrossRef]

22. Zhao, G.H.; Ketov, S.V.; Mao, H.H.; Borgenstam, A.; Louzguine-Luzgin, D.V. Ti-Fe-Sn-Nb hypoeutectic alloys with superb yield strength and significant strain-hardening. Scripta Mater. 2017, 135, 59-62. [CrossRef]

23. Zadorozhnyy, V.Y.; Shi, X.; Kozak, D.S.; Wada, T.; Wang, J.Q.; Kato, H.; Louzguine-Luzgin, D.V. Electrochemical behavior and biocompatibility of Ti-Fe-Cu alloy with high strength and ductility. J. Alloys Compd. 2017, 707, 291-297. [CrossRef] 
24. Ruzic, J.; Emura, X.; Ji, X.; Watanabe, I. Mo segregation and distribution in Ti-Mo alloy investigated using nanoindentation. Mater. Sci. Eng. A 2018, 718, 48-55. [CrossRef]

25. Timoshenko, S.; Goodier, J.N. Theory of Elasticity, 2nd ed.; Mcgraw-Hill: New York, NY, USA, 1951.

26. Jeong, H.W.; Kim, S.E.; Hyun, Y.T.; Lee, Y.T.; Park, J.K. Microstructures and elastic moduli of binary titanium alloys containing biocompatible alloying elements. Mater. Sci. Forum 2005, 475-479, 2291-2294. [CrossRef]

27. Gornakova, A.S.; Straumal, B.B.; Nekrasov, A.N.; Kilmametov, A.; Afonikova, N.S. Grain boundary wetting by a second solid phase in Ti-Fe alloys. J. Mater. Eng. Perform. 2018, 27, 4989-4992. [CrossRef]

28. Gornakova, A.S.; Prokofiev, S.I.; Straumal, B.B.; Kolesnikova, K.I. Growth of ( $\alpha \mathrm{Ti})$ Grain-Boundary layers in Ti-Co alloys. Russ. J. Non-Ferr. Met. 2016, 57, 703-709. [CrossRef]

29. Takeuchi, A.; Inoue, A. Classification of bulk metallic glasses by atomic size difference, heat of mixing and period of constituent elements and its application to characterization of the main alloying element. Mater. Trans. 2005, 46, 2817-2829. [CrossRef]

30. Fischer, F.D.; Reisner, G.; Werner, E.; Tanaka, K.; Cailletaud, G.; Antretter, T. A new view on transformation induced plasticity (TRIP). Int. J. Plast. 2000, 16, 723-748. [CrossRef]

31. Li, P.Y. Microstructure and mechanical properties of rapidly solidified B2-type Zr-Co alloys containing a second phase of $\mathrm{Zr}_{2}$ Co. Mater. Res. Express 2018, 5, 046522. [CrossRef]

32. Haghighi, S.E.; Liu, Y.J.; Cao, G.H.; Zhang, L.C. Phase transition, microstructural evolution and mechanical properties of Ti-Nb-Fe alloys induced by Fe addition. Mater. Des. 2016, 97, 279-286. [CrossRef]

33. Fornell, J.; Van Steenberge, N.; Varea, A.; Rossinyol, E.; Pellicer, E.; Suriñach, S.; Baró, M.D.; Sort, J. Enhanced mechanical properties and in vitro corrosion behavior of amorphous and devitrified $\mathrm{Ti}_{40} \mathrm{Zr}_{10} \mathrm{Cu}_{38} \mathrm{Pd}_{12}$ metallic glass. J. Mech. Behav. Biomed. Mater. 2011, 4, 1709-1717. [CrossRef]

34. Musil, J.; Kunc, F.; Zeman, H.; Poláková, H. Relationships between hardness, Young's modulus and elastic recovery in hard nanocomposite coatings. Surf. Coat. Technol. 2002, 154, 304-313. [CrossRef]

35. Haghighi, S.E.; Cao, G.H.; Zhang, L.C. Nanoindentation study of mechanical properities of Ti based alloys with Fe and Ta additions. J. Alloys Compds. 2017, 692, 892-897. [CrossRef]

36. Medeiros, B.B.; Medeiros, M.M.; Fornell, J.; Sort, J.; Baró, M.D.; Jorge Junior, A.M. Nanoindentation response of $\mathrm{Cu}$-Ti based metallic glasses: Comparison between as-cast, relaxed and devitrified states. J. Non-Cryst. Solids 2015, 425, 103-109. [CrossRef] 